\title{
Mechanistic Studies on the Base-Promoted Conversion of Alkoxy-Substituted, Ring-Fused gem-Dihalocyclopropanes into Furans: Evidence for a Process Involving Electrocyclic Ring Closure of an Oxonium Ylide Intermediate
}

Patrick P. Sharp, , Jiri Mikusek, ${ }^{a}$ Junming Ho, ${ }^{a}$ Elizabeth H. Krenske, ${ }^{a}$ Martin G. Banwell, , ,a Michelle L. Coote, ${ }^{\mathrm{a}, \mathrm{b}}$ Jas S. Ward ${ }^{\mathrm{a}}$ and Anthony C. Willis ${ }^{\mathrm{a}}$

${ }^{a}$ Research School of Chemistry, Institute of Advanced Studies

The Australian National University, Canberra, ACT 2601, Australia

\section{${ }^{b}$ ARC Centre of Excellence for Electromaterials Science}

The mechanism associated with the base-promoted conversion of alkoxy-substituted and ring-fused gem-dihalocyclopropanes such as $\mathbf{4 0}$ into annulated furans has been explored. Treatment of compound $\mathbf{4 0}$ with potassium tert-butoxide affords a mixture of furans $23 / 27$ and 41, an outcome that suggests the intermediacy of the slowly interconverting oxonium ylides $\mathbf{4 2}$ and $\mathbf{4 3}$ that undergo rapid [1,5]-electrocyclisations and subsequent dehydrohalogenation to afford the observed products. This proposal is supported by $a b$ initio MO and DFT calculations that also suggest a vinylcarbene insertion pathway is less likely to be operative.
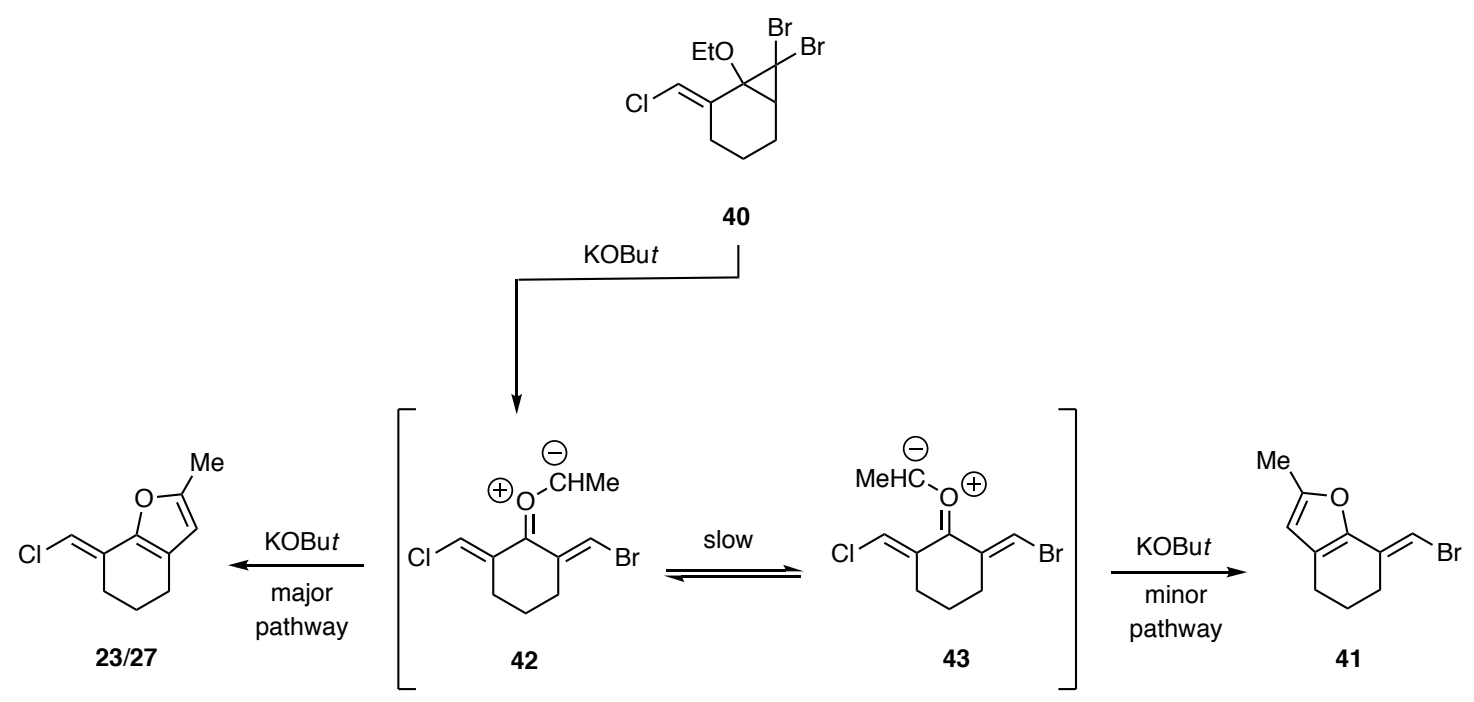


\section{Introduction}

gem-Dihalocyclopropanes are readily prepared by addition of the relevant dihalocarbene to the corresponding alkene ${ }^{I}$ and we have demonstrated that these kinetically stable but distinctly strained three-membered carbocycles are useful building blocks in natural products synthesis. ${ }^{2}$ In one aspect of our activities in this area, we reported that treatment of compound 1 (Figure 1) with potassium tert-butoxide in THF affords the ring-cleaved product 2 (56\% at $87 \%$ conversion), the structure of which was established by single-crystal X-ray analysis. ${ }^{3} \mathrm{We}$ have since used this ring-cleavage reaction in the assembly of tetracyclic frameworks related to the gibberellins. ${ }^{4}$ However, before seeking to apply this rather unusual process more extensively, we sought to develop an understanding of its mechanism.
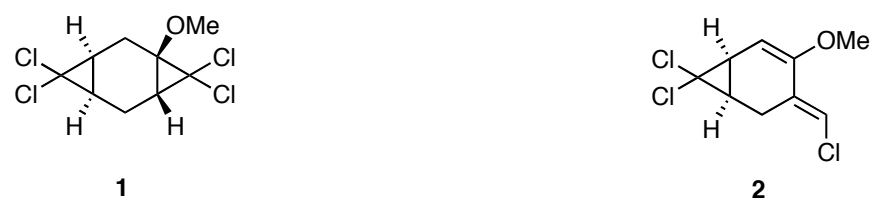

Figure 1: Starting alkoxy-substituted and ring-fused gem-dichlorocyclopropane $\mathbf{1}$ and the derived, base-induced elimination product 2

The working hypothesis we established is shown in Scheme 1 and involves an initial basepromoted elimination of the elements of $\mathrm{HCl}$ from substrate $\mathbf{1}$ so as to form the ring-fused cyclopropene 3. The regioselectivity associated with this first step may be attributed to a directed ortho-metallation (DoM) type-process ${ }^{5}$ whereby the methoxy group facilitates deprotonation and concomitant kaliation at the adjacent cyclopropyl centre. The resulting anion then engages in the second step of an $\mathrm{E} 1_{\mathrm{cb}}$ process to give cyclopropene $\mathbf{3}$, related examples of which have been trapped in Diels-Adler cycloaddition reactions. ${ }^{6}$ Rearrangement of compound 3 to the corresponding "vinylcarbene" 4 might be expected" and this latter species could then undergo a proton transfer reaction to give the oxonium ylide $\mathbf{5}$. The transformation $\mathbf{4} \rightarrow \mathbf{5}$ accounts for the E-configuration about the exocyclic double bond within the final product (2) that would be formed by a proton transfer within intermediate $\mathbf{5}$. 
Scheme 1: Possible reaction pathway associated with the base-promoted conversion of the alkoxy-substituted and ring-fused gem-dichlorocyclopropane $\mathbf{1}$ into diene $\mathbf{2}$.

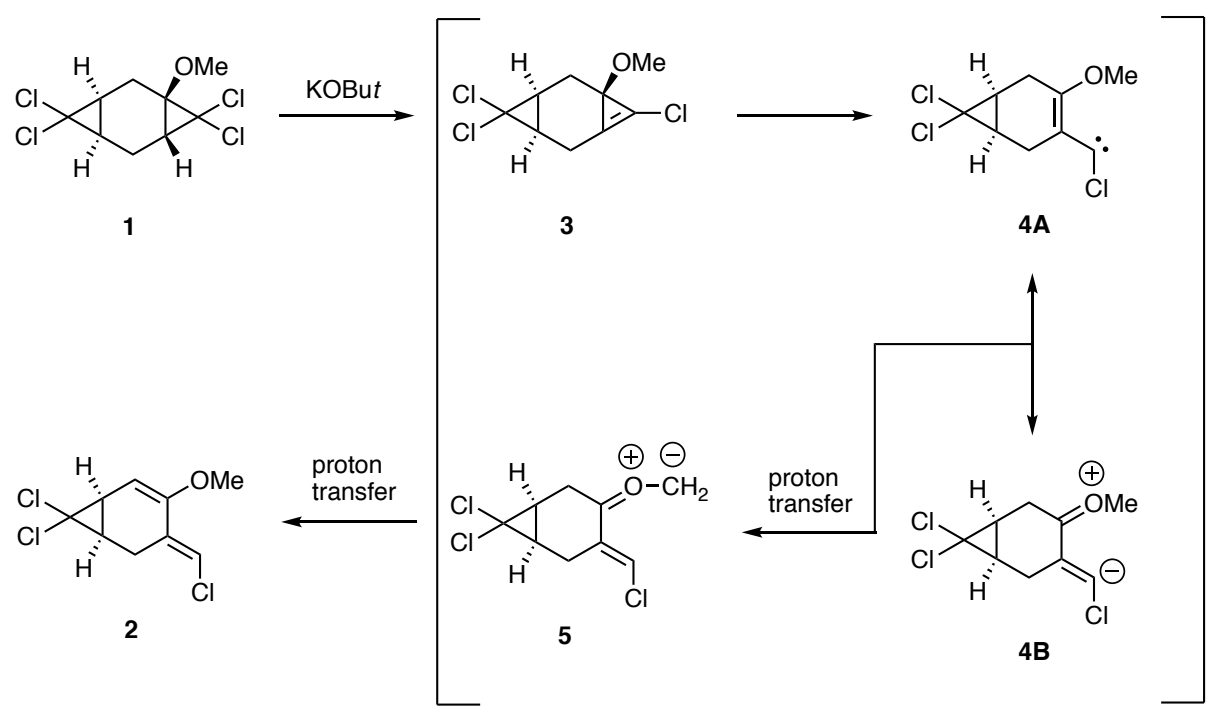

As part of an effort to intercept such proposed oxonium ylide intermediates, the basepromoted reaction of a substrate incapable of engaging in a final proton transfer was investigated..$^{8}$ To this end, the dichlorocarbene adduct, 6 (Figure 2), of 1-methoxy-3,4dihydronaphthalene was treated with potassium tert-butoxide in THF and the annulated furan 7 thus obtained in $72 \%$ yield. The ethoxy-equivalent, 8 , of compound $\mathbf{6}$ was converted into the corresponding C2-methylated furan 9 (88\%) under the same conditions. Such conversions provide a useful method for forming annulated furans and one that we have exploited in the total synthesis of the racemic modification of the furanosesquiterpene pallescensin A. ${ }^{8}$

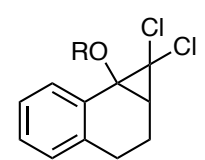

$6 \mathrm{R}=\mathrm{Me}$ $8 \mathrm{R}=\mathrm{Et}$

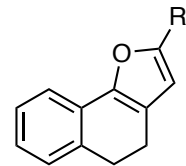

$7 \mathrm{R}=\mathrm{H}$
$9 \mathrm{R}=\mathrm{Me}$

Figure 2: Alkoxy-substituted and ring-fused gem-dichlorocyclopropanes $\mathbf{6}$ and $\mathbf{8}$ and the derived, annulated furans $\mathbf{7}$ and $\mathbf{9}$

Two reaction pathways can be envisaged to account for the conversions $6 \rightarrow \mathbf{7}$ and $\mathbf{8} \rightarrow \mathbf{9}$. The first of these (Scheme 2) would involve initial base-promoted elimination of the elements of $\mathrm{HCl}$ from substrate $\mathbf{6}$ or $\mathbf{8}$ and rearrangement of the resulting cyclopropene, $\mathbf{1 1}$ and $\mathbf{1 2}$ 
respectively to the corresponding vinylcarbene $\mathbf{1 3}$ or $\mathbf{1 4}$. Insertion of the latter species into one of the $\mathrm{C}-\mathrm{H}$ bonds of the pendant alkoxy-group would give the chlorodihydrofuran $\mathbf{1 5}$ or 16 that then loses the elements of a second equivalent of $\mathrm{HCl}$ to afford the observed and fully aromatic heterocycle $\mathbf{7}$ or $\mathbf{9}$. This pathway is closely related to that proposed by Müller and Paute ${ }^{9}$ to account for the base-promoted conversion of the dichlorocarbene adduct of 9methoxyphenanthrene into phenanthro[9,10-b]furan .

Scheme 2: The vinylcarbene C-H insertion pathway leading from cyclopropanes $\mathbf{6}$ and $\mathbf{8}$ to the annulated furans 7 and 9

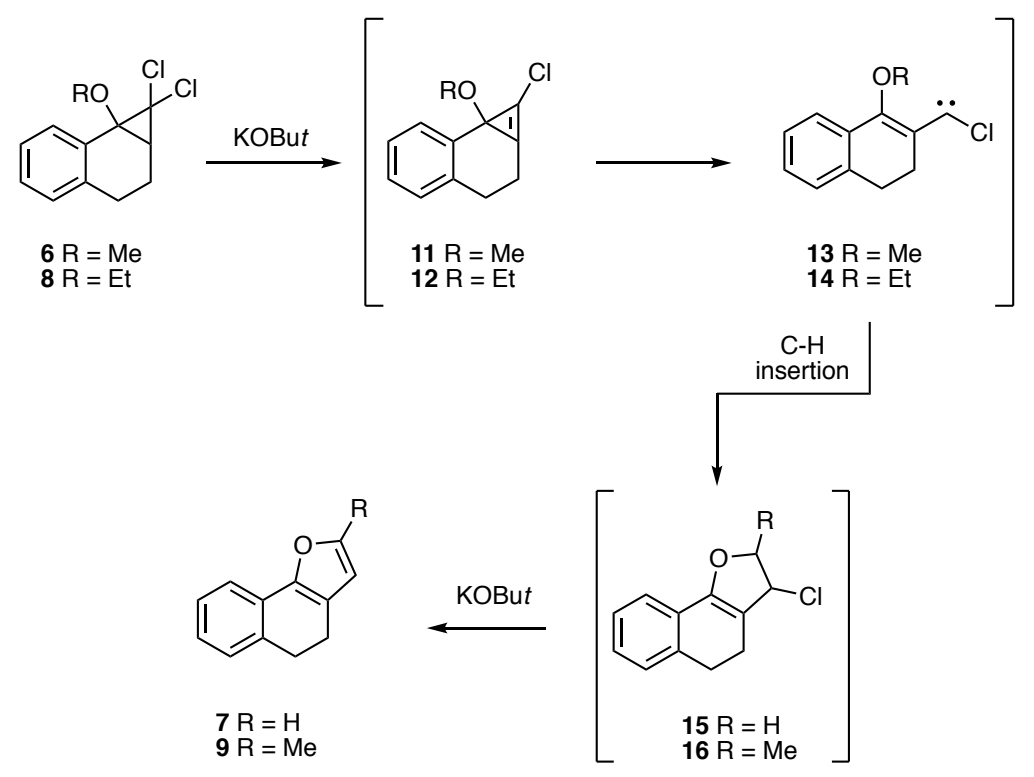

An alternate reaction pathway that seems more consistent with the one proposed for the conversion $\mathbf{1} \rightarrow \mathbf{2}$ is shown in Scheme 3. Thus, as with the pathway proposed immediately above, this also involves initial formation of cyclopropene $\mathbf{1 1}$ or $\mathbf{1 2}$ and the subsequent conversion of these into the corresponding vinylcarbenes 13 and 14, respectively. These can each be represented in the corresponding zwitterionic forms $\mathbf{1 3 B}$ and $\mathbf{1 4 B}$. Now, rather than participating in a carbene insertion reactions, these latter species undergo intermolecular proton transfers to give the oxonium ylides $\mathbf{1 7}$ and $\mathbf{1 8}$ that then engage in $6 \pi$-electron electrocyclic ring closures $\{[1,5] \text {-electrocyclisation }\}^{10}$ to give the chlorodihydrofurans $\mathbf{1 5}$ and 16 that lose the elements of $\mathrm{HCl}$ to give the observed products 7 and $\mathbf{9}$, respectively. The intervention of the electrocyclisation process in the present cases is the consequence of a lack of a proton-transfer pathway available to ylides $\mathbf{1 7}$ and $\mathbf{1 8}$ (but which is available to congener 
5 and which is presumably the faster of the two processes in that particular case). When various 1,3-dipolarophiles (e.g. parent furan) were added to such reaction mixtures no adducts arising from the trapping of oxonium ylides were observed, mostly likely because of the significant kinetic advantage of the available intramolecular reaction pathways.

Scheme 3: The oxonium ylide pathway leading from cyclopropanes $\mathbf{6}$ and $\mathbf{8}$ to the corresponding annulated furans $\mathbf{7}$ and 9

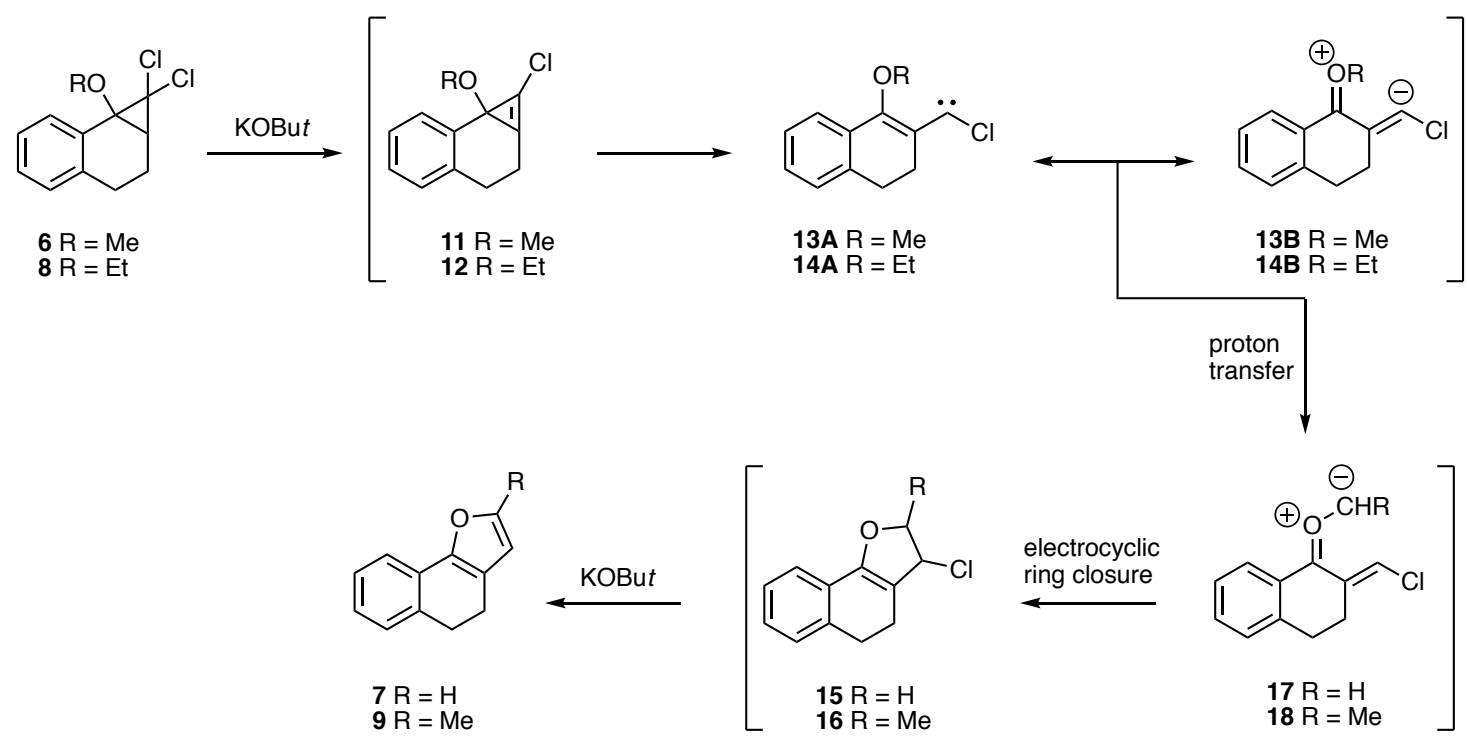

The objective of the present work was to establish the validity or otherwise of the mechanistic proposals shown in Schemes 2 and 3. These studies were of both a theoretical and experimental nature. Details are presented in the following section. 


\section{Results and Discussion}

\section{Theoretical Studies}

High-level quantum chemical calculations were performed (see Experimental Section for details) to determine the transition state energies for the carbene insertion $(\mathbf{1 3} \rightarrow \mathbf{1 5})$, the proton transfer $(\mathbf{1 3 B} \rightarrow \mathbf{1 7})$ and the electrocyclic ring closure steps $(\mathbf{1 7} \rightarrow \mathbf{1 5})$ shown in Schemes 2 and 3. The analogous transition state energies were also calculated for the system lacking the annulated benzene ring and the one in which the chlorines of 13,15 and 17 had been replaced by bromines. In all cases, the calculations revealed that the activation enthalpy for the carbene insertion process is much higher that that associated with either the proton transfer or electrocyclisation processes. Indeed, attempts to locate a transition state for carbene $\mathrm{C}-\mathrm{H}$ insertion were unsuccessful. Instead, the formation of the dihydrofuran appears to take place in two steps with initial proton transfer to form $\mathbf{1 7}$ followed by an electrocyclic ring-closure to form dihydrofuran $\mathbf{1 5}$. The barrier for proton transfer is, overall, rate-limiting at $0{ }^{\circ} \mathrm{C}$ and approximately $74 \mathrm{~kJ} \mathrm{~mol}^{-1}$ (inclusive of tunneling correction - tunneling lowers the barrier to proton transfer by approximately $5 \mathrm{~kJ} \mathrm{~mol}^{-1}$ ). This barrier translates to a half-life of approximately $0.3 \mathrm{mins}$, consistent with the observed conversions being complete in 2 hours or less. The overall energy profile for this more favorable pathway is presented in Figure 3. Clearly, then, such relatively high-level theoretical studies suggest the pathway shown in Scheme 3 will be favored over the one shown in Scheme 2.

Two other noteworthy features of the energetically favored pathway were revealed through these theoretical studies. A comparison of the geometries (bond lengths and angles) as well as calculated (NBO) atomic charges of 13A and 13B suggest that the "vinylcarbene" is better represented in its zwitterionic form (viz. 13B). Further, the potentially competing reaction pathway wherein ylide $\mathbf{1 7}$ cyclizes to form the isomeric spiro-epoxide was also considered (since there is the possibility that the reaction could be "trapped" in a kinetic well as this spiro-epoxide). The relevant calculations revealed that the barrier to the formation the spiroepoxide is about $30 \mathrm{~kJ} \mathrm{~mol}^{-1}$ higher than that associated with the formation of the dihydrofuran $\mathbf{1 5}$ and is, therefore, unlikely to be kinetically competitive. 


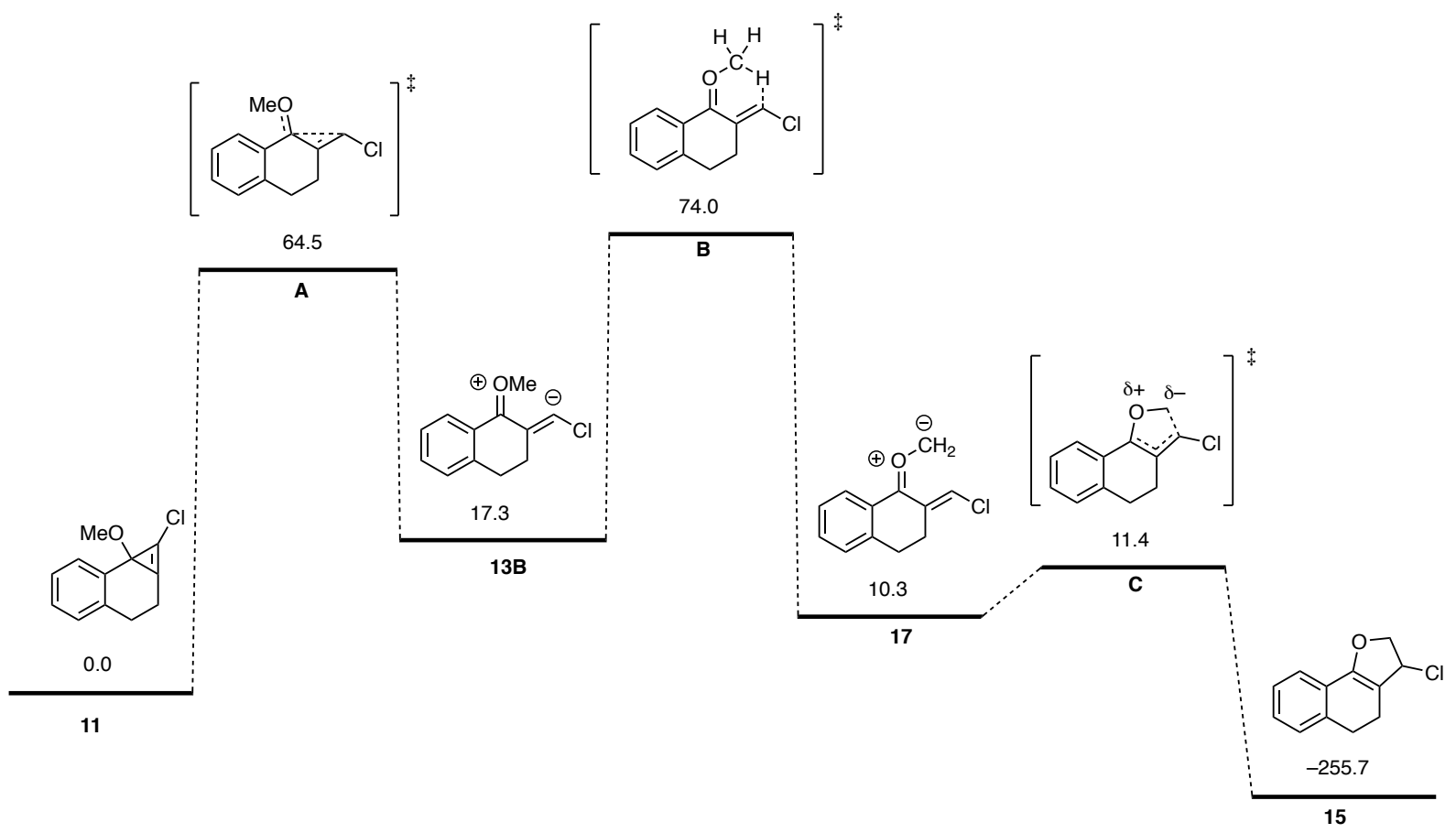

Figure 3: Gibbs free energy profile $\left(\mathrm{kJ} \mathrm{mol}^{-1}\right)$ for the conversion of the cyclopropene $\mathbf{1 1}$ into corresponding dihydrofuran 15 in THF at $0{ }^{\circ} \mathrm{C}$ (values shown are relative to ring-fused cyclopropene 11). Calculations performed at the G3(MP2)-RAD- $(+) / / B 3 L Y P / 6-31+G(d, p)$ level of theory in conjunction with SMD solvent corrections.

\section{Experimental Studies}

The devising of experimental studies that would differentiate between the pathways shown in Schemes 2 and 3 became the next focus of our efforts. Details of studies that appear to do so are presented in the following sections.

\section{Investigations of the Proposed Reaction Pathways Using ${ }^{13}$ C-labeling}

\section{Experiments}

If compound $\mathbf{1 9}^{11}$ (Scheme 4) were available and would engage in the same sort of basepromoted reaction that has been observed for congeners $\mathbf{6}$ and $\mathbf{8}$ then the two alternate reaction pathways that might be followed in producing furan $\mathbf{2 3}$ are those depicted in Schemes 4 and 5. Thus, the first pathway (Scheme 4) involves the "usual" base-promoted elimination of the elements of $\mathrm{HCl}$ from the substrate $\mathbf{1 9}$ to generate the cyclopropene $\mathbf{2 0}$. Rearrangement of this highly strained species to the corresponding vinylcarbene $\mathbf{2 1}$ would then be followed by carbene insertion into one of the methylene $\mathrm{C}-\mathrm{H}$ bonds of the pendant OEt unit and thus affording chlorodihydrofuran 22. This loses another molecule of $\mathrm{HCl}$ to give the C2-methylated furan 23. Should such a reaction sequence be carried out on a substrate carrying a ${ }^{13} \mathrm{C}$-label $(\bullet)$ at the geminally dichlorinated carbon then this should appear, exclusively, at the illustrated (protonated) carbon, C2, of the furan ring in the product. 
Scheme 4: The conversion, via a carbene-insertion pathway, of ${ }^{13} \mathrm{C}$-labelled gemdichlorocyclopropane 19 into furan 23.

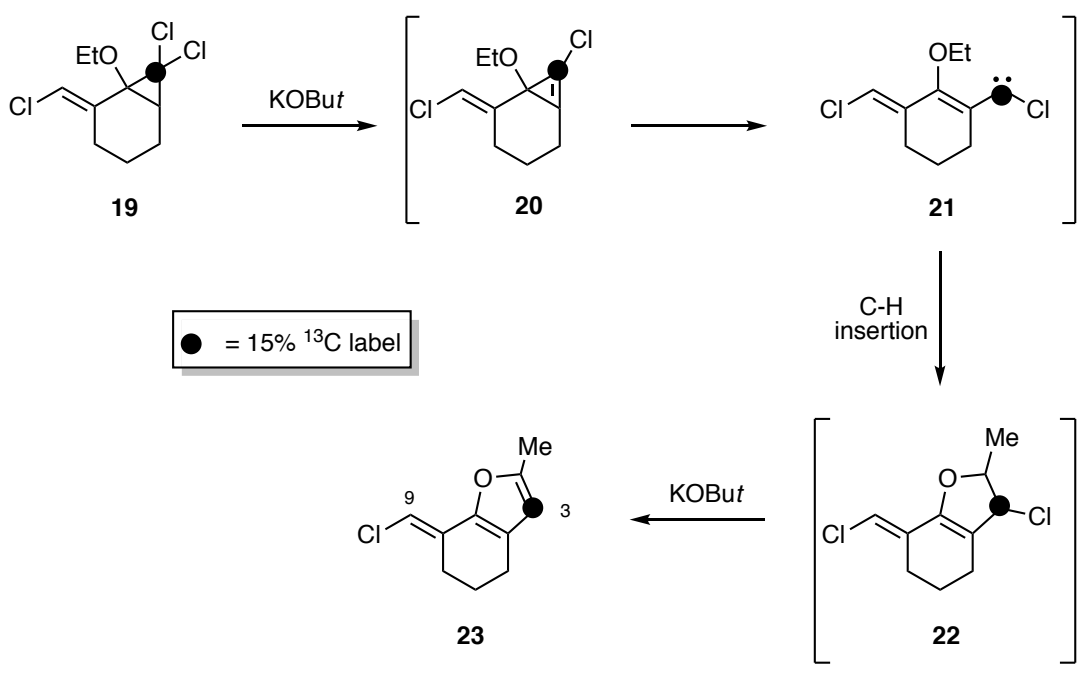

On the other hand, if the reaction pathway from substrate 19 to product 23 follows the alternate pathway shown in Scheme 5 then a different distribution of the ${ }^{13} \mathrm{C}$-label should be observed. Thus, the oxonium ylide $\mathbf{2 4}$ derived from proton transfer within vinylcarbene $\mathbf{2 1}$ is a pseudo-symmetrical species that should be able to isomerize about the ylide subunit to give compound 25 that only differs from its precursor by virtue of the presence of the ${ }^{13} \mathrm{C}$-label. Each of compounds $\mathbf{2 4}$ and $\mathbf{2 5}$ could engage in electrocyclic ring closure reactions to give the chlorodihydrofurans $\mathbf{2 2}$ and 26, respectively. This latter pair of compounds would then lose the elements of $\mathrm{HCl}$ to give furans $\mathbf{2 3}$ and 27 differing only in the positions of the ${ }^{13} \mathrm{C}$-label $(\bullet)$ within the molecular framework. Thus, the two possible pathways shown in Schemes 4 and 5 could, in principle at least, be distinguished by the nature of the distribution of the ${ }^{13} \mathrm{C}$ label $(\bullet)$ within the product furan. In particular, the carbene insertion route would lead to a site-specifically labeled furan whilst the proton-transfer/electrocyclic ring-closure pathway might be expected to result in scrambling of the same label within the product furan. Accordingly, the preparation of compound 19 was pursued. 
Scheme 5: The conversion, via ylide 1,5-electrocyclisation pathways, of ${ }^{13} \mathrm{C}$-labelled $\mathrm{gem}$ dichlorocyclopropane 19 into the isotopomeric furans 23 and 27.

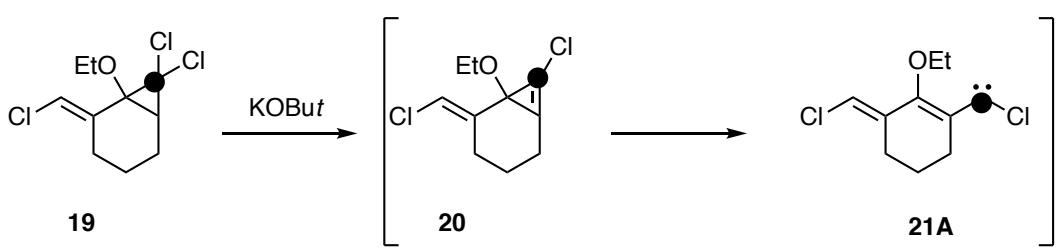

$=15 \%{ }^{13} \mathrm{C}$ label
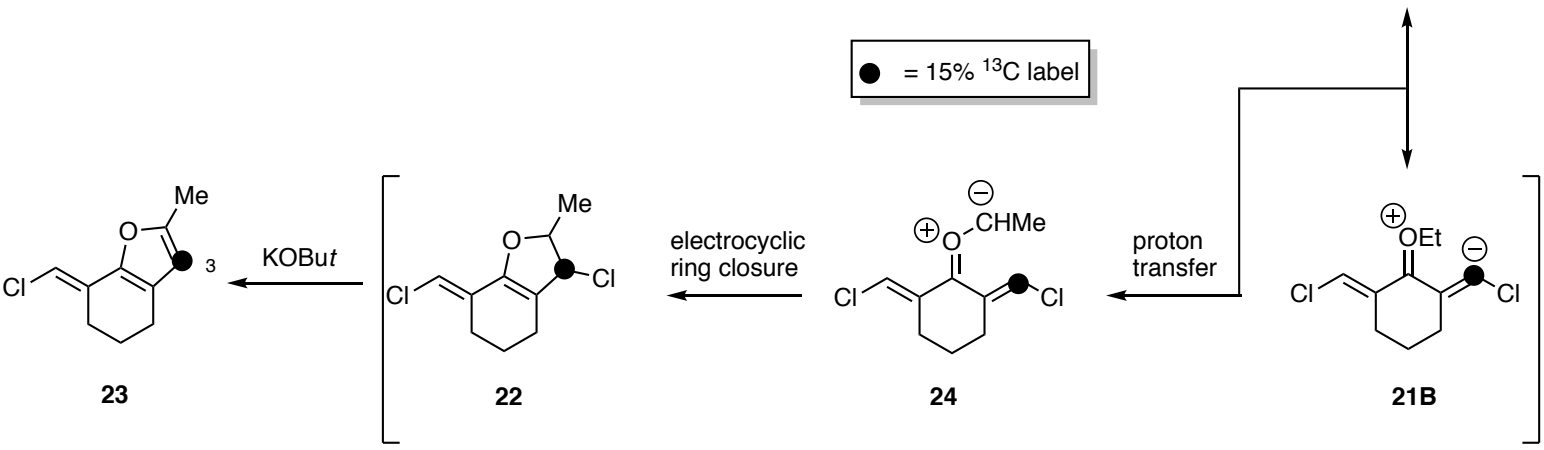

electrocyclic ring closure<smiles>C[C-]=C1C(=CCl)CCCC1=CCl</smiles>

24

isotopomer interconversion<smiles>CC=C1CCCc2cc(C)oc21</smiles>

27

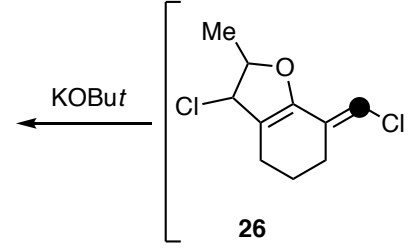

26

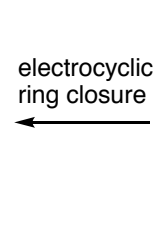

Syntheses of the non-labeled form of compound 19 and its methoxy-substituted counterpart were established using the route shown in Scheme 6. Thus, cyclohexanone (28) was converted into 1-ethoxycyclohexene (29) ${ }^{12}$ under standard conditions involving initial formation of the corresponding diethyl ketal and cracking of this at high $\left(150{ }^{\circ} \mathrm{C}\right)$ temperatures. 1Methoxycyclohexene (30) ${ }^{12}$ was prepared by analogous means and in essentially the same yield. Dichlorocarbene, generated from chloroform and sodium hydroxide in the presence of a phase transfer catalyst, ${ }^{13}$ was then added to alkenes $\mathbf{2 9}$ and $\mathbf{3 0}$ thus affording the previously reported cyclopropanes $31^{14}$ and $\mathbf{3 2}^{6}$ in yields of $54 \%$ and $73 \%$, respectively. Independent treatment of the latter compounds with potassium tert-butoxide, in the same manner as employed for conversions such as $\mathbf{1} \rightarrow \mathbf{2}$, afforded the expected but rather unstable dienes $\mathbf{3 3}$ and $\mathbf{3 4}$ in yields of $91 \%$ and 90\%, respectively. Compounds $\mathbf{3 3}$ and $\mathbf{3 4}$ were immediately reacted with dichlorocarbene and the required cyclopropanes 19 and 35 thus obtained in yields of $70 \%$ and $65 \%$, respectively. All the spectral data derived from these materials were in accord with the assigned structures. Definitive confirmation of these came from single 
crystal X-ray analyses of both the ethoxy- and methoxy-substituted systems $\mathbf{1 9}$ and $\mathbf{3 5}$, respectively. Relevant data are presented in Experimental Section and the Supporting Information (SI).

Scheme 6: The synthesis of the gem-dichlorocyclopropanes 19 and 35 from cyclohexanone (28)

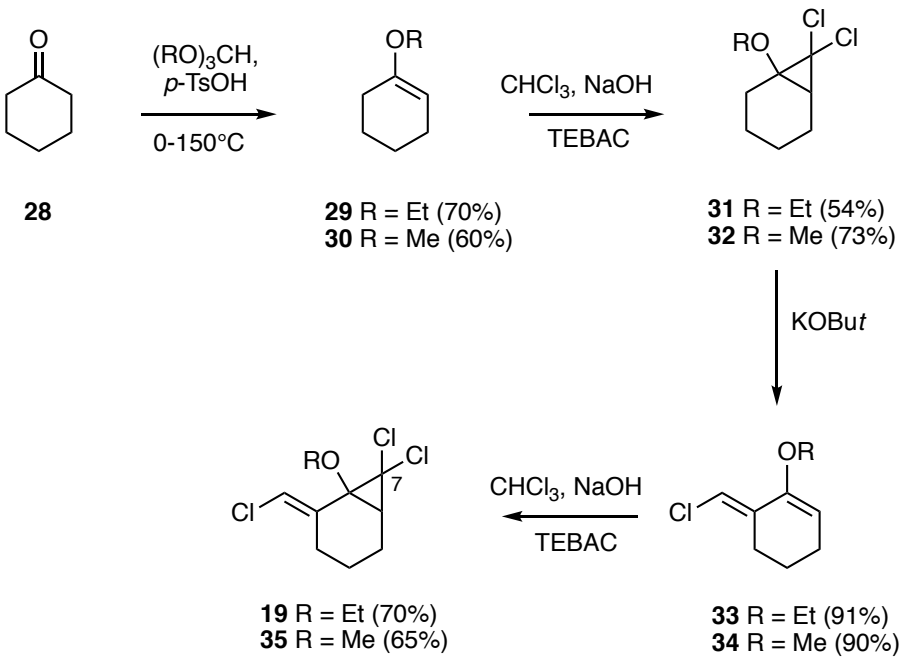

With the unlabelled compounds $\mathbf{1 9}$ and $\mathbf{3 5}$ to hand these were subjected to reaction with potassium tert-butoxide (Scheme 7) and the expected furans 23/27 and $\mathbf{3 6}$ thus obtained as clear colorless oils in $82 \%$ and $35 \%$ yields respectively. The spectral data derived from these rather unstable materials were, once again, in complete accord with the assigned structures. As a prelude to the foreshadowed isotope-labeling studies, various COSY and other experiments were conducted on compound $23 / 27$ in order to fully assign the $\left\{{ }^{1} \mathrm{H}\right\}{ }^{13} \mathrm{C}$ NMR spectrum (Figure 3). 
Scheme 7: Base-induced conversion of the alkoxy-substituted, gem-dichlorocyclopropanes 19 and $\mathbf{3 5}$ into the corresponding annulated furans and the Diels-Alder adduct, 38, and its aromatic isomer $\mathbf{3 9}$ derived from one of these.<smiles>OC1(Cl)C(Cl)=C(Cl)CCCC1Cl</smiles><smiles>C[Mg]C(C)=O</smiles><smiles>CC(=O)C#CC(C)=O</smiles>
$19 \mathrm{R}=\mathrm{Et}$
$35 \mathrm{R}=\mathrm{Me}$ 23/27 R = Me (82\%)

37 $36 \mathrm{R}=\mathrm{H}(35 \%)$

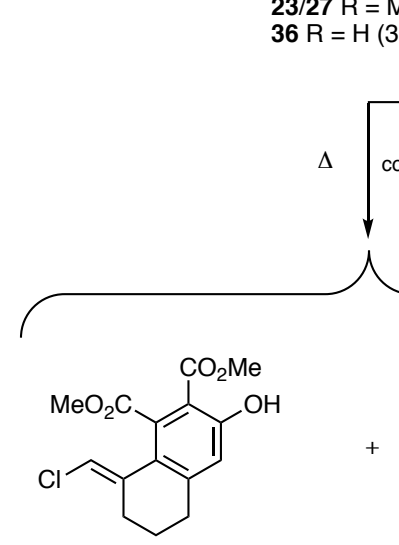

39

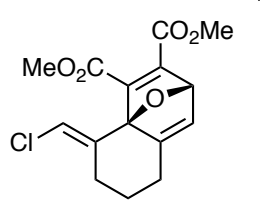

38

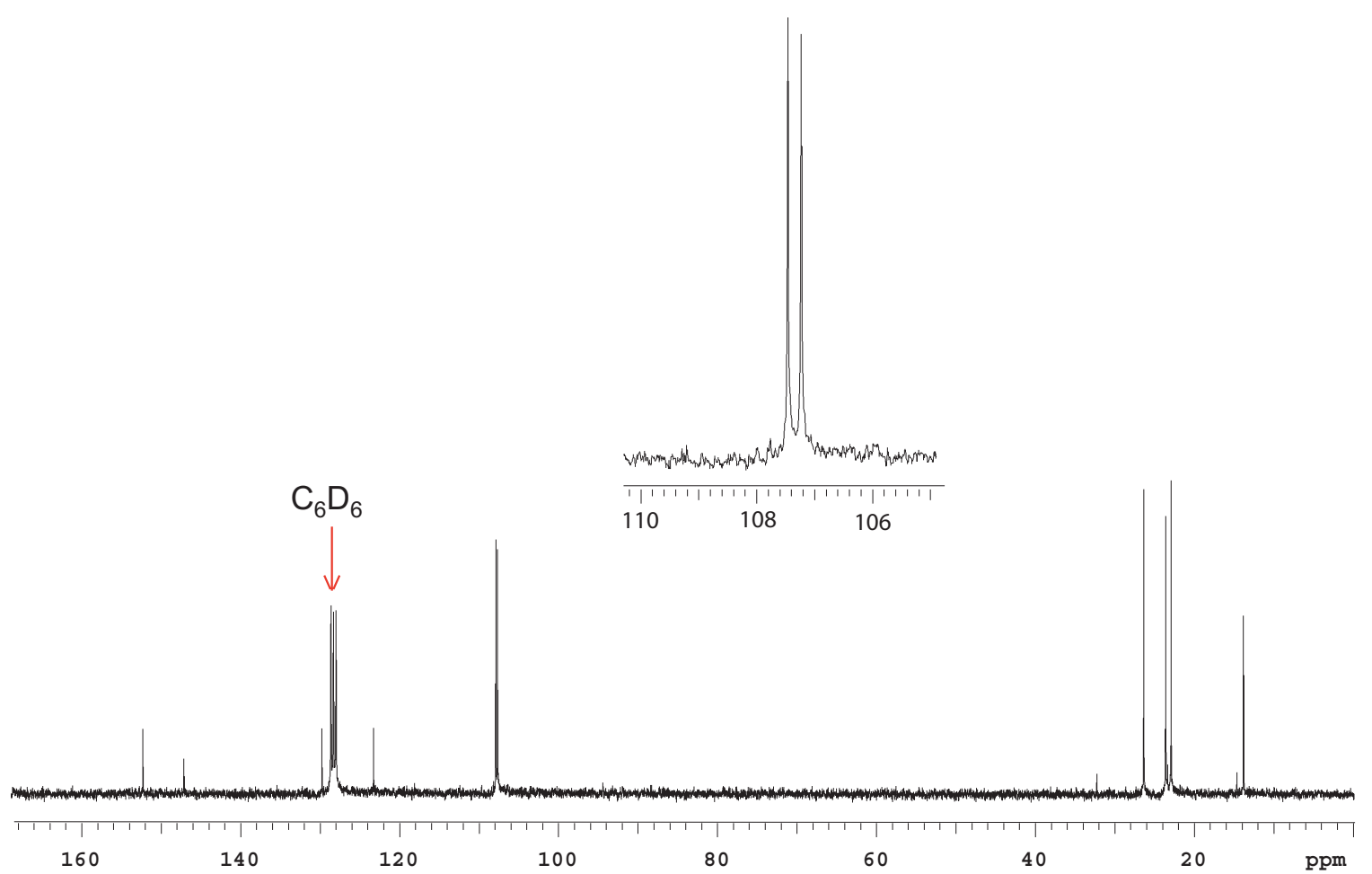

Figure 3: The $75 \mathrm{MHz}\left\{{ }^{1} \mathrm{H}\right\}{ }^{13} \mathrm{C}$ NMR spectrum of the unlabelled form of compound 23/27 (recorded in $\mathrm{C}_{6} \mathrm{D}_{6}$ ) 
In an effort to obtain a crystalline derivative, compound $\mathbf{3 6}$ was heated in toluene with equimolar quantities of dimethyl acetylenedicarboxylate (DMAD, 37). Depending on the temperature employed, then either the adduct, 38, arising from a Diels-Alder reaction, or its aromatized isomer 39 were obtained albeit in rather modest yields (Scheme 7). Unfortunately, and despite many attempts, neither compound $\mathbf{3 8}$ or $\mathbf{3 9}$ could be crystallized. Efforts to effect an analogous cycloaddition reaction between compound 23/27 and DMAD failed.

The foregoing results indicated that the proposed ${ }^{13} \mathrm{C}$-labelling studies were viable. Accordingly, the $\mathrm{ca} .15 \%{ }^{13} \mathrm{C}$-labelled form of substrate 19 was prepared by treating the diene precursor 33 with $15 \%{ }^{13} \mathrm{C}$-labelled chloroform and aqueous sodium hydroxide in the presence of TEBAC. A comparison of the ${ }^{13} \mathrm{C}$ NMR spectra of both the labeled and unlabeled forms of compound 19 (both recorded in $\mathrm{C}_{6} \mathrm{D}_{6}$ ) revealed, in the spectrum of the latter material, a $c a$. 13-fold enhancement in the resonance at $\delta 70.0$ which is assigned to the gemdichlorocyclopropyl carbon $\mathrm{C} 7$. Reaction of the ${ }^{13} \mathrm{C}$-labelled substrate 19 with potassium tertbutoxide under the same conditions as described earlier resulted in the clean conversion of it into the expected furan. ${ }^{13} \mathrm{C}$ NMR analysis of chromatographically purified samples of this material (Figure 4) established that, within the limits of experimental error, the ${ }^{13} \mathrm{C}$-label $(\bullet)$ had been incorporated only into that carbon giving rise to a resonance at $\delta 107.5$ and which had been assigned to $\mathrm{C} 3$. 


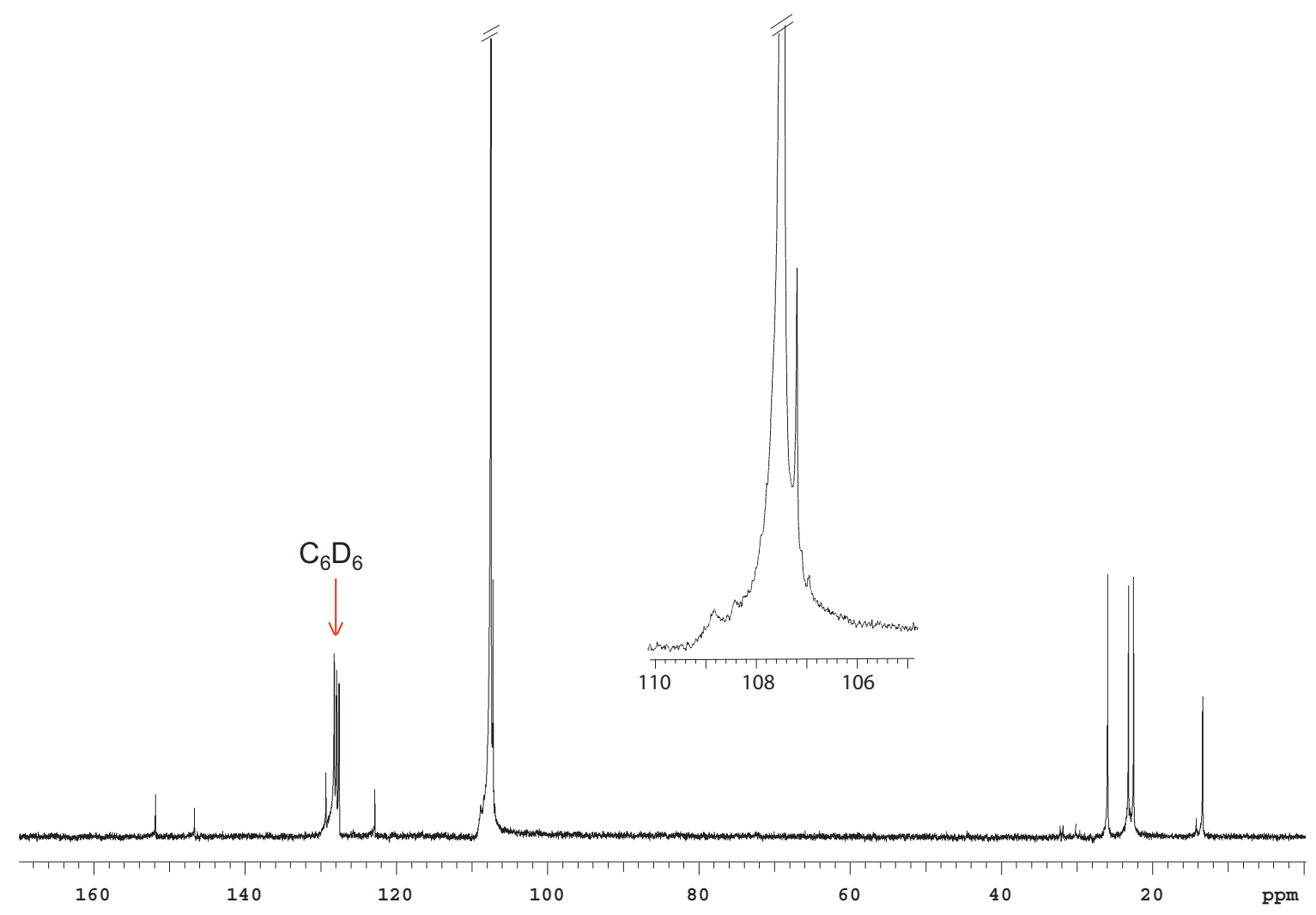

Figure 4: The $75 \mathrm{MHz}\left\{{ }^{1} \mathrm{H}\right\}{ }^{13} \mathrm{C}$ NMR spectrum of the $c a .15 \%{ }^{13} \mathrm{C}$-labelled compound 23 (recorded in $\mathrm{C}_{6} \mathrm{D}_{6}$ )

Accordingly, the product furan is assigned as compound $\mathbf{2 3}$ and not an admixture of it with isotopomer 27. On the face of it, then, this outcome is only consistent with the carbene insertion pathway presented in Scheme 4. However, a partitioning of the label between C2 and C9, as would be expected from operation of the pathway shown in Scheme 5, will only be observed if the interconversion of isotopomers $\mathbf{2 4}$ and $\mathbf{2 5}$ proceeds at a rate that is competitive with the electrocyclic ring closure of these ylides. Certainly, the theoretical calculations detailed above suggest that the latter process has a very small/low activation enthalpy. Interestingly, high level ab initio MO theory and DFT calculations reveal that the barrier to rotation about the ylide bond in the non-labelled form of compound $\mathbf{2 4 / 2 5}$ is $40.0 \mathrm{~kJ} / \mathrm{mole}$ at 0 ${ }^{\circ} \mathrm{C}\left(\mathrm{k}=7.6 \times 10^{4} \mathrm{~s}^{-1}\right)$ and $39.9 \mathrm{~kJ} /$ mole at $25{ }^{\circ} \mathrm{C}\left(\mathrm{k}=3.6 \times 10^{5} \mathrm{~s}^{-1}\right)$. Accordingly, it is conceivable that the ylide pathway shown in Scheme 5 is operative but there is no detectable (within experimental error) "scrambling" of the ${ }^{13} \mathrm{C}$-label $(\bullet)$ because of this relatively high barrier to interconversion of isotopomers $\mathbf{2 4}$ and $\mathbf{2 5}$. 


\section{Investigations of the Proposed Reaction Pathway Using Halogen-labeling Experiments}

Given the results and interpretations just described, it became important to devise experiments that could provide a capacity for more definitive detection of scrambling of label (if this was indeed occurring). The outcomes of an experiment that does so are presented below.

Subjecting the gem-dibrominated analogue, 40 (Figure 5), of compound 19 to reaction with potassium tert-butoxide could produce at least two possible outcomes. The first of these, which would be encountered if the carbene insertion pathway (see Scheme 4) were followed, would involve the exclusive production of the previously observed chloro-furan $\mathbf{2 3} / \mathbf{2 7}$.

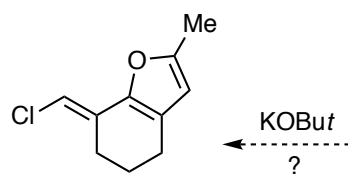

$23 / 27$

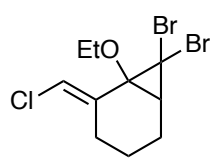

40

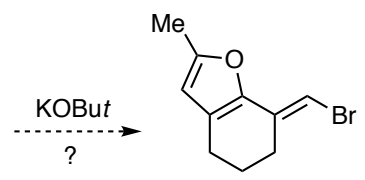

41

Figure 5: Substrate $\mathbf{4 0}$ and the possible products, 23/27 and 41, of its reaction with base

In contrast, if the oxonium ylide pathway (Scheme 8) were followed and if the initially formed ylide 42 could rearrange to isomer 43 , at least to some extent and prior to the electrocyclisation reaction, then a mixture of chloro-furan $23 / 27$ and its bromo-counterpart 41 might be observed. Even if the chlorinated system still predominated, since these two furans are distinctly different by virtue of the variation in the nature of the associated halogen then the presence of even rather small quantities of the brominated system $\mathbf{4 1}$ should be detectable by mass spectrometric methods. 
Scheme 8: Possible outcomes of the reaction of the gem-dibromocyclopropane $\mathbf{4 0}$ with base and involving oxonium ylide intermediates

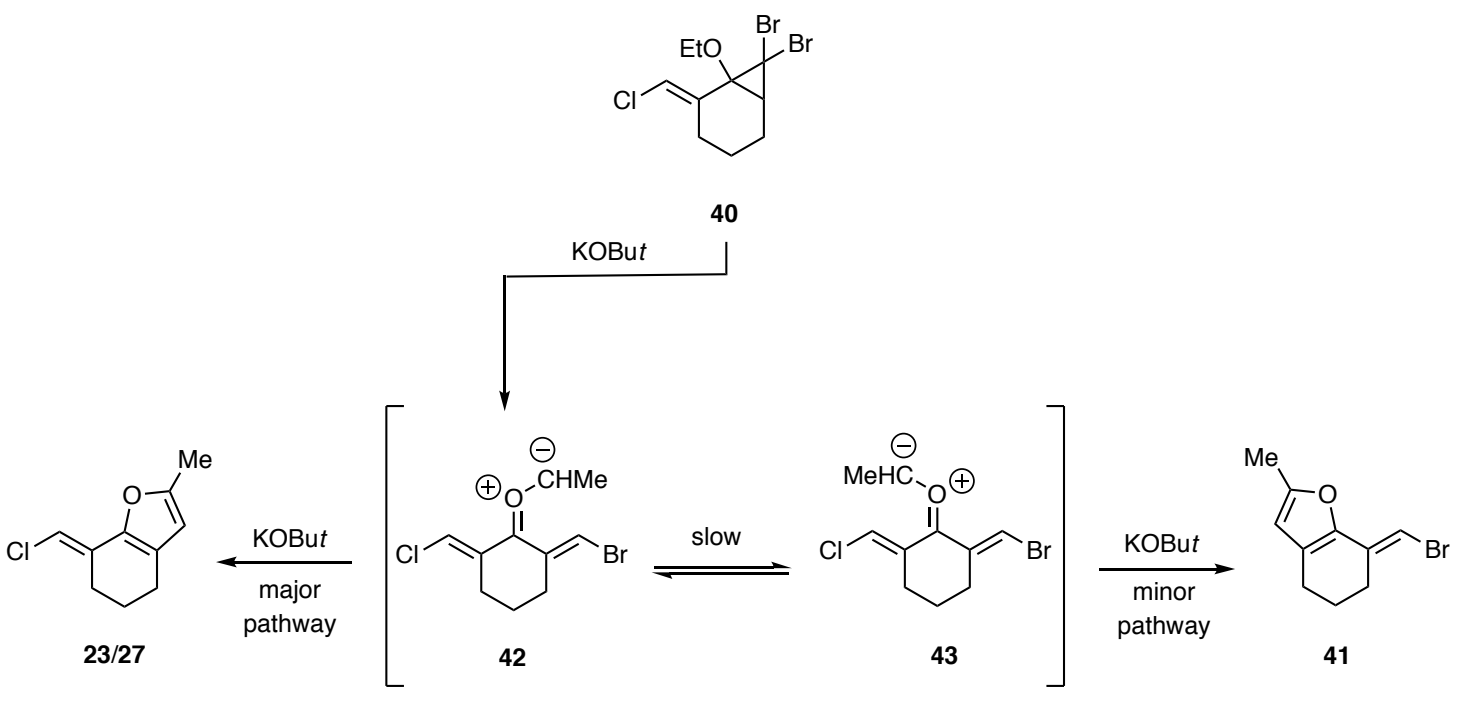

The requisite gem-dibromocyclopropane $\mathbf{4 0}$ was readily prepared, in 51\% yield, by selective addition of dibromocarbene to diene $\mathbf{3 3}$ and the structure of the product cyclopropane confirmed by single-crystal X-ray analysis (see Experimental and SI for details). When compound 40 was treated with potassium tert-butoxide, under the (by now) standard conditions for furan formation, and the reaction mixture obtained on work-up subjected to GC-MS analysis then the major product proved to be the expected chlorinated furan $\mathbf{2 3 / 2 7}$, the $70 \mathrm{eV}$ EI mass spectrum of which is shown in Figure 6a. However, a chromatographically less mobile reaction component present at the $2-3 \%$ level (relative to the major product) gave a $70 \mathrm{eV}$ EI mass spectrum (Figure 6b) entirely consistent with that expected for the brominated furan 41. 


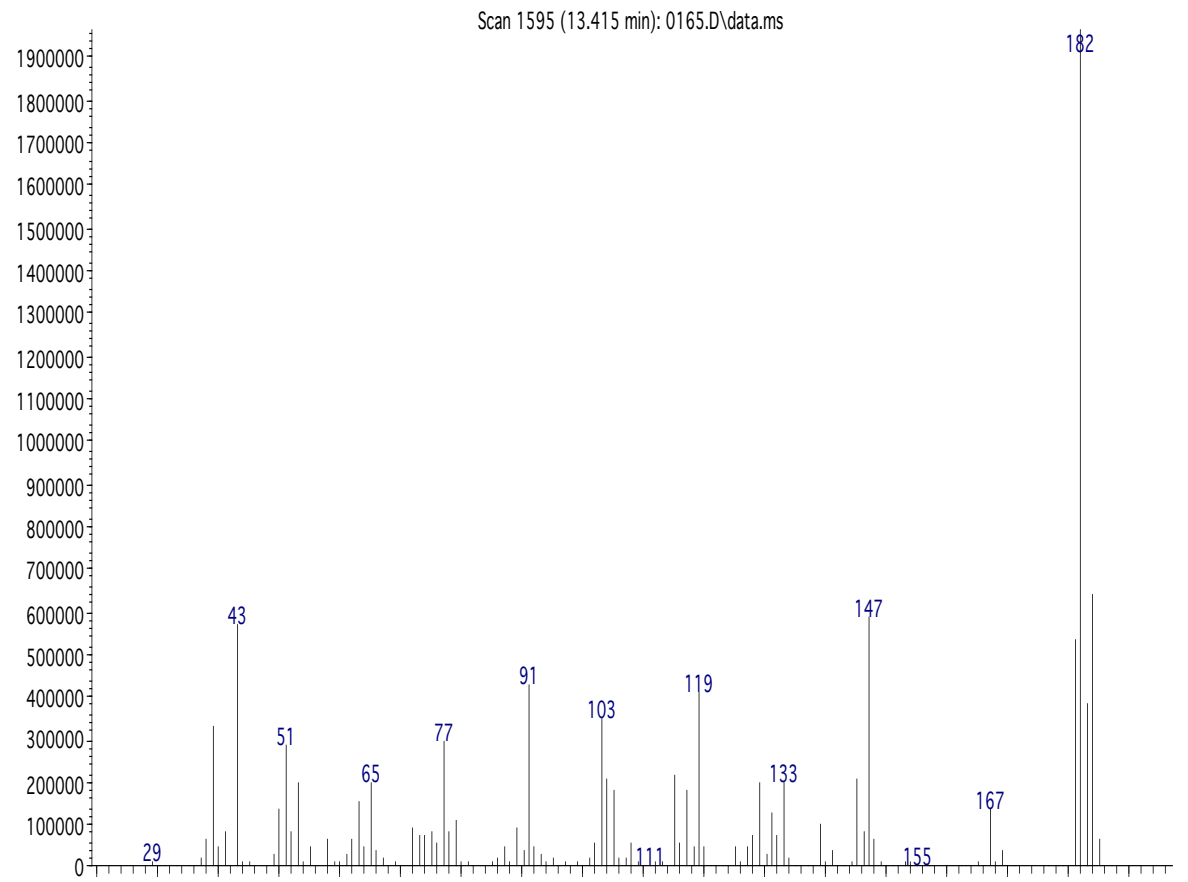

Abundance

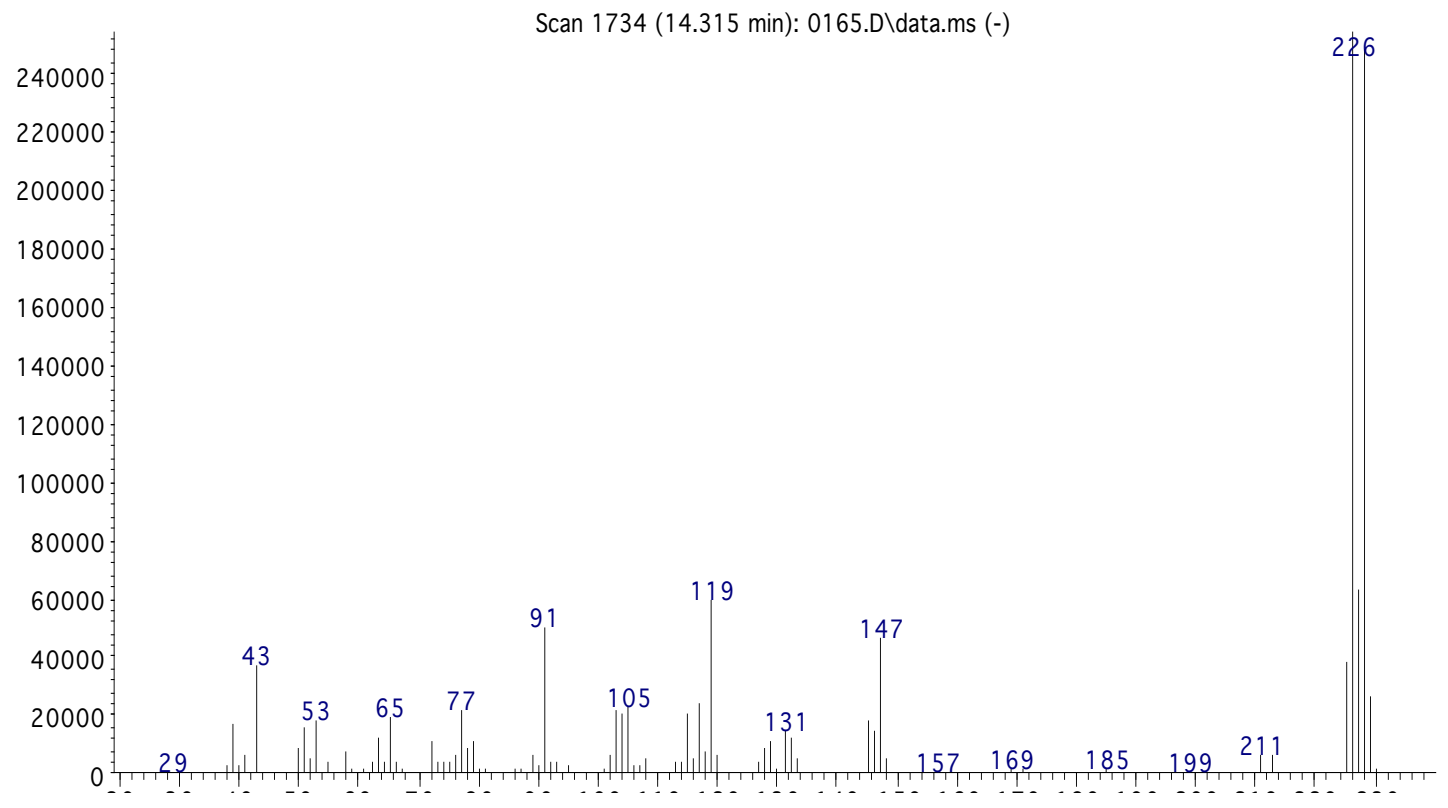

Figure 6: (a) top: $70 \mathrm{eV}$ EI mass spectrum of chlorofuran 23/27 isolated by GC from the reaction of gem-dibromocyclopropane $\mathbf{4 0}$ with potassium tert-butoxide; (b) bottom: $70 \mathrm{eV} \mathrm{EI}$ mass spectrum of the corresponding and co-formed bromofuran $\mathbf{4 1}$

In particular, the correct pair of molecular ions is observed at $m / z 226$ and 228 and, as with the analogous spectrum of congener $\mathbf{2 3} / \mathbf{2 7}$, loss of atomic bromine results in a daughter ion with $m / z$ 147. The remaining fragment ions observed in the mass spectrum of bromofuran 41 parallel those observed in the equivalent spectrum of the chlorinated system $23 / 27$. So, whilst we have not been able to isolate compound $\mathbf{4 1}$ from this reaction, including by using HPLC 
techniques, the data just described strongly indicate that this material has been co-produced with its chlorinated analogue. Accordingly, we take this result as indicating that the oxonium ylide $\mathbf{4 2}$ is an intermediate in the conversion $\mathbf{4 0} \rightarrow \mathbf{2 3 / 2 7}+\mathbf{4 1}$ and that this species is partially converted into isomer $\mathbf{4 3}$ prior to the electrocyclic ring closure event and thus giving rise to "scrambling" of the halogen label.

An experiment complementary to that just described would be the one shown in Scheme 9 and wherein the compound $\mathbf{4 4}$ was now the substrate to be treated with base. In this case the oxonium ylide $\mathbf{4 3}$ should be formed preferentially and then undergo electrocyclization and subsequent elimination to form the brominated furan $\mathbf{4 1}$ as the major product. That said, some isomerization of ylide 43 to congener 42 could occur and thus leading to at least the coproduction of small amounts of the chlorofuran $23 / 27$.

Scheme 9: Possible outcomes of the reaction of the gem-dibromocyclopropane 44 with base.
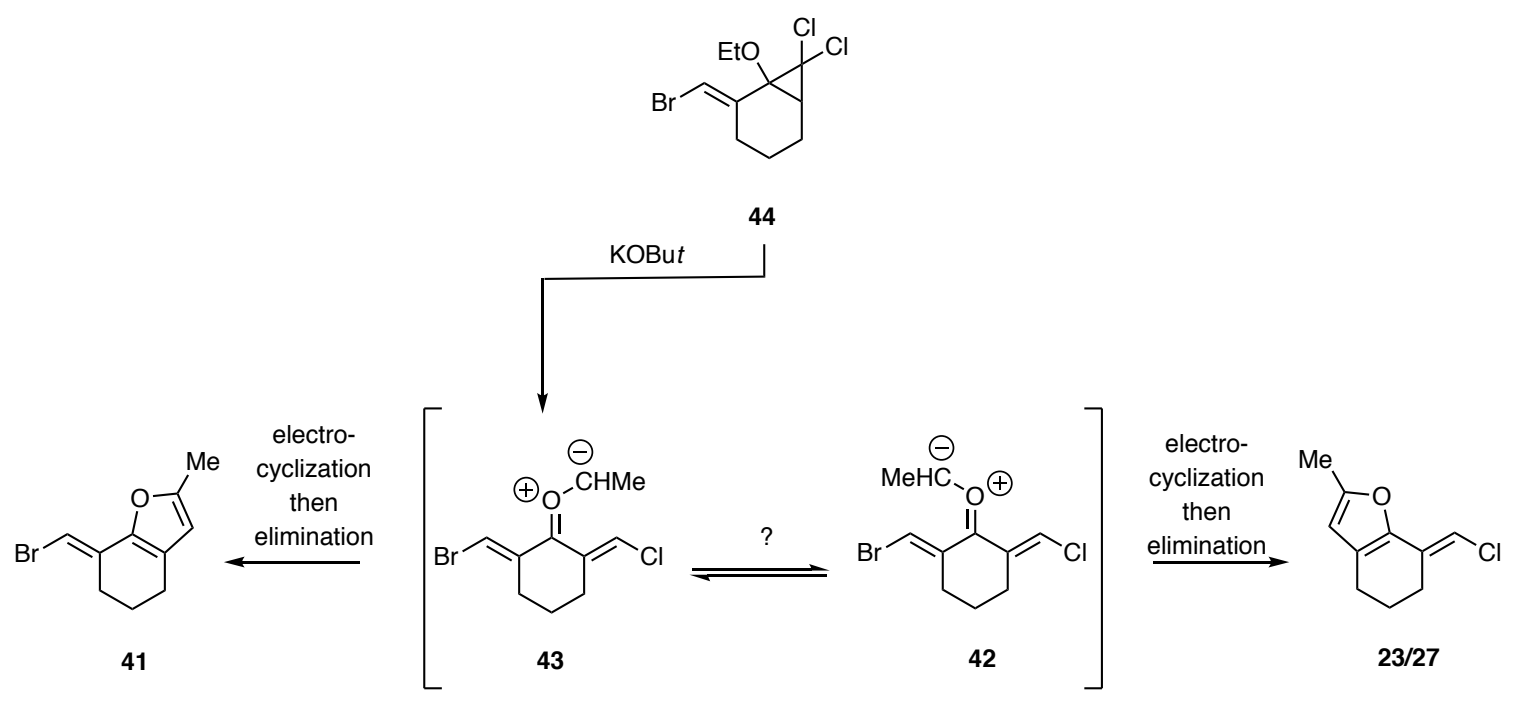

Investigating the proposal shown in Scheme 9 necessitated the acquisition of compound 44 and the outcomes of our attempts to do so are shown in Scheme 10. Thus, dibromocarbene addition to enol ether 29 proceeded as expected to afford the anticipated adduct $\mathbf{4 5}^{14}(61 \%)$. However, on treating this last compound with potassium tert-butoxide diene $\mathbf{4 6}$ failed to form. Rather, a 2:5 mixture of the $\beta$-alkoxycycloheptenones 47 and 48 was obtained in $71 \%$ combined yield. As such the reaction pathways postulated in Scheme 9 could not be investigated. 
Scheme 10: Attempted synthesis of gem-dichlorocyclopropane 44 via intermediate 46. Unanticipated formation of the $\beta$-alkoxycycloheptenones 47 and 48.

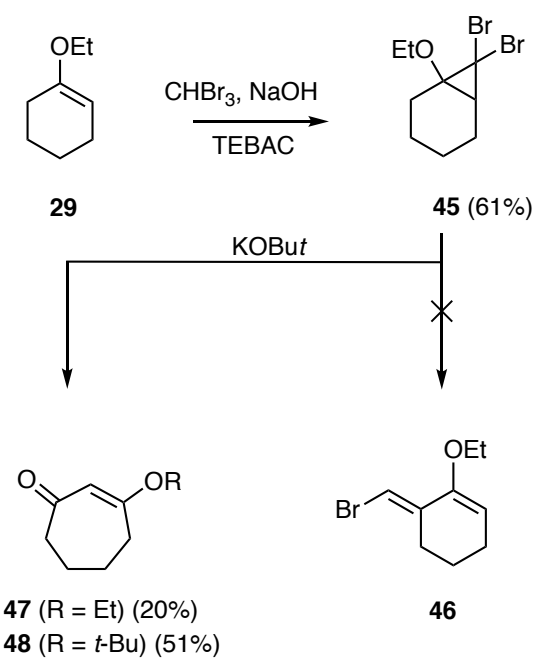

\section{Conclusions}

The foregoing theoretical and experimental studies provide evidence for the involvement of a hitherto unrecognized reaction pathway associated with the base-promoted conversion of the title cyclopropanes into furans. Whether this pathway operates in competition with the previously proposed carbene insertion mechanism? remains unclear although the theoretical studies detailed here would suggest not. The potential utility of this kind of process is highlighted by our observation that treatment of the dichlorocarbene adducts of certain enamines with strong base leads to pyrroles, ${ }^{15}$ presumably by a reaction pathway analogous to the one defined in Scheme 3.

\section{Experimental Section}

\section{General Experimental Procedures}

Melting points were measured on a Stanford Research Systems Optimelt - Automated Melting Point System and are uncorrected. Proton $\left({ }^{1} \mathrm{H}\right)$ and carbon $\left({ }^{13} \mathrm{C}\right)$ NMR spectra were recorded on a Bruker 800, 600, 400 or a Varian Gemini 300 NMR spectrometer. Unless otherwise specified, spectra were acquired at $20^{\circ} \mathrm{C}$ in deutero-chloroform $\left(\mathrm{CDCl}_{3}\right)$ or benzene $\left(C_{6} D_{6}\right)$ that had been filtered through basic alumina immediately prior to use. Chemical shifts are recorded as $\delta$ values in parts per million (ppm). The signal due to residual $\mathrm{CHCl}_{3}$ appearing at $\delta_{\mathrm{H}} 7.26$ and the central resonance of the $\mathrm{CDCl}_{3}$ "triplet" appearing at $\delta_{\mathrm{C}}$ 77.0 were used to reference ${ }^{1} \mathrm{H}$ and ${ }^{13} \mathrm{C}$ NMR spectra, respectively. Infrared spectra $\left(v_{\max }\right)$ 
were recorded on a Perkin-Elmer 1800 Series FTIR Spectrometer and samples were analyzed as $\mathrm{KBr}$ disks (for solids) or as thin films on $\mathrm{KBr}$ plates (for oils). Low resolution mass spectra were recorded on a Micromass-Waters LC-ZMD single quadrupole liquid chromatographMS or a VG Quattro II triple quadrupole MS instrument. High resolution mass spectra were recorded on an AUTOSPEC spectrometer. Dichloromethane (DCM) was distilled from calcium hydride and THF was distilled, under nitrogen, from sodium benzophenone ketyl or these same solvents were dried using a purification system based on technology originally described by Grubbs et al. ${ }^{16}$ Where necessary, reactions were performed under a nitrogen atmosphere. Flash chromatography was carried out according to the protocols defined by Still et al. ${ }^{17}$

\section{Theoretical Studies}

All electronic structure calculations were carried out using Gaussian09 ${ }^{18}$ and Molpro 2009.1. ${ }^{19}$ The geometries and vibrational frequencies were obtained at the B3LYP/6$31+G(d, p)$ level of theory. The gas phase electronic energies were obtained at the G3(MP2)RAD $-(+)^{20}$ level of theory, where $(+)$ signifies that calculations with the 6-31G(d) basis set has been replaced with the $6-31+G(d)$ basis set so as to allow for an improved description for the electronic structure of the zwitterionic species. The thermal corrections to the Gibbs free energies were obtained using scaled harmonic frequencies ${ }^{21}$ at $0{ }^{\circ} \mathrm{C}$. The solvation free energies in THF were computed using the SMD solvent model ${ }^{22}$ also at the B3LYP/6$31+\mathrm{G}(\mathrm{d}, \mathrm{p})$ level of theory. The tunnelling correction to the rate of proton transfer was calculated using the Eckart method, ${ }^{23}$ using the vibrationally adiabatic potential energy surface obtained using the SMD solvent model at the B3LYP/6-31+G(d,p) level of theory. NBO atomic charges were obtained at the B3LYP/6-311+G(3df,2p) level of theory.

\section{Synthetic Studies}

\section{General Procedure for the Formation of gem-Dihalocyclopropanes}

A mixture of finely powdered sodium hydroxide $(2.40 \mathrm{~g}, 60.0 \mathrm{mmol})$ and triethylbenzyl ammonium chloride (TEBAC) (114 mg, $0.5 \mathrm{mmol}$ ) was added to a vigorously stirred solution of the corresponding alkene $(10 \mathrm{mmol})$ in dichloromethane $(2.5 \mathrm{~mL})$ maintained at $0{ }^{\circ} \mathrm{C}$ (ice/water bath). The relevant haloform (30 mmol) was then added, dropwise, to the reaction mixture then the reaction vessel was fitted with a Liebig condenser and maintained under a nitrogen atmosphere. The ice/water bath was removed and the reaction mixture thus obtained allowed to warm to $22{ }^{\circ} \mathrm{C}$. A vigorous exotherm and associated foaming of the reaction mixture was often observed after ca. 0.5 to $2 \mathrm{~h}$ and the ensuing dark-brown slurry was cooled, 
after $3 \mathrm{~h}$, then filtered through a $5 \mathrm{~cm}$ deep pad of diatomaceous earth contained in a sintered glass funnel. The solids thus retained were washed with dichloromethane until the washings appeared colorless. The combined filtrates were concentrated under reduced pressure to give a dark-brown oil that was subjected to flash chromatography.

\section{General Procedure for the Reaction of gem-Dihalocyclopropanes with t-BuOK}

A solution of commercially obtained potassium tert-butoxide $(2.24 \mathrm{~g}, 20.0 \mathrm{mmol})$ in THF (10 $\mathrm{mL}$ ) was added, dropwise, to a magnetically stirred solution of the corresponding gemdihalocyclopropane $(10.0 \mathrm{mmol})$ in THF $(5 \mathrm{~mL})$ maintained under a nitrogen atmosphere at 0 ${ }^{\circ} \mathrm{C}$ (ice/water bath). After $0.25 \mathrm{~h}$ the reaction mixture was quenched with $\mathrm{NaHCO}_{3}(15 \mathrm{~mL}$ of a saturated aqueous solution) and the resulting mixture partitioned between diethyl ether (30 $\mathrm{mL})$ and water $(10 \mathrm{~mL})$. The separated aqueous phase was extracted with diethyl ether $(3 \times 20$ $\mathrm{mL})$ and the organic extracts combined, dried $\left(\mathrm{Na}_{2} \mathrm{SO}_{4}\right)$ and then filtered through a No. 3 porosity sintered glass funnel. The filtrate was concentrated under reduced pressure and the resulting oil subjected to flash chromatography.

\section{E-7,7-Dichloro-2-(chloromethylene)-1-ethoxybicyclo[4.1.0]heptane (19)}

The title compound 19 was prepared from (6E)-6-chloromethylene-1-ethoxycyclohexene (33) (500 mg, $2.90 \mathrm{mmol})$ using the general method for the formation of gem-dihalocyclopropanes as described above. The dark-brown oil obtained after work-up was subjected to flash chromatography (silica, 99:1 $\rightarrow$ 98:2 $\mathrm{v} / \mathrm{v}$ hexane/ethyl acetate gradient elution) and concentration of the appropriate fractions $\left(R_{\mathrm{f}}=0.5\right.$ in $9: 1 \mathrm{v} / \mathrm{v}$ hexane/ethyl acetate $)$ then afforded E-7,7-dichloro-2-(chloromethylene)-1-ethoxybicyclo[4.1.0]heptane (19) $(520 \mathrm{mg}$, $70 \%$ ) as a white, crystalline solid, m.p. $=47-50{ }^{\circ} \mathrm{C}$ (recrystallized from $\mathrm{CH}_{2} \mathrm{Cl}_{2} /$ hexane). ${ }^{1} \mathrm{H}$ NMR (400 MHz, $\left.\mathrm{CDCl}_{3}\right) \delta 6.57(\mathrm{~s}, 1 \mathrm{H}), 3.58(\mathrm{~m}, 1 \mathrm{H}), 3.37(\mathrm{~m}, 1 \mathrm{H}), 2.61(\mathrm{~m} \mathrm{1H}), 2.27-2.16$ (complex m, 1H), 2.01-1.88 (complex m, 2H), 1.71-1.56 (complex m, 2H), 1.31-1.18 (complex m, 4H); ${ }^{1} \mathrm{H}$ NMR (300 MHz, $\left.\mathrm{C}_{6} \mathrm{D}_{6}\right) \delta 6.47(\mathrm{~s}, 1 \mathrm{H}), 3.10(\mathrm{~m}, 1 \mathrm{H}), 2.81(\mathrm{~m}, 1 \mathrm{H}), 2.31$ $(\mathrm{m}, 1 \mathrm{H}), 1.77(\mathrm{~m}, 1 \mathrm{H}), 1.47(\mathrm{~m}, 2 \mathrm{H}), 1.17(\mathrm{~m}, 2 \mathrm{H}), 0.91(\mathrm{t}, J=7.0 \mathrm{~Hz}, 3 \mathrm{H}), 0.72(\mathrm{~m}, 1 \mathrm{H}) ;{ }^{13} \mathrm{C}$ $\mathrm{NMR}\left(100 \mathrm{MHz} \mathrm{CDCl}_{3}\right) \delta 132.5,120.4,69.2,65.9,63.6,35.0,25.8,20.8,20.1,15.1 ;{ }^{13} \mathrm{C}$ NMR $\left(75 \mathrm{MHz}, \mathrm{C}_{6} \mathrm{D}_{6}\right) \delta 133.2,120.9,70.0,66.2,63.6,35.3,26.3,21.2,20.3,15.4 ; \mathrm{IR} v_{\max }$ 2978, 2942, 1616, 1445, 1111, 1052, 833, $781 \mathrm{~cm}^{-1}$; MS m/z (EI, $\left.70 \mathrm{eV}\right) 221$ and 219 [(M$\mathrm{Cl} \bullet)^{+}, 88$ and 99\%], 193 and 191 (98 and 100), 163 (54), 155 (98), 125 (80), 109 (93), 91 (94); HRMS found: $(\mathrm{M}-\mathrm{Cl} \bullet)^{+}, 219.0341 . \mathrm{C}_{10} \mathrm{H}_{13}{ }^{35} \mathrm{Cl}_{3} \mathrm{O}$ requires $(\mathrm{M}-\mathrm{Cl} \bullet)^{+}, 219.0343$.

The ca. $15 \% \mathrm{C} 7{ }^{13} \mathrm{C}$-labeled form of compound 19 was obtained using the same procedure as defined above but using ca. $15 \%{ }^{13} \mathrm{C}$-labeled chloroform in place of natural abundance 
material. Comparison of the ${ }^{13} \mathrm{C}$ NMR spectra of the unlabeled and labeled materials indicated a ca. 15 fold enhancement of the signal at $\delta_{C}\left(75 \mathrm{MHz}, \mathrm{C}_{6} \mathrm{D}_{6}\right) 70.0$ in the latter case.

\section{E-7-(Chloromethylene)-4,5,6,7-tetrahydro-2-methylbenzofuran (23/27)}

The title compound (23/27) was prepared from E-7,7-dichloro-2-(chloromethylene)-1ethoxybicyclo[4.1.0]heptane (19) $(195 \mathrm{mg}, 0.76 \mathrm{mmol})$ using the general method for treating of gem-dihalocyclopropanes with $t$-BuOK described above. The dark-brown oil obtained after work-up was subjected to flash chromatography (silica, 99:0 $\rightarrow$ 98:2 v/v hexane/ethyl acetate gradient elution) and concentration of the appropriate fractions $\left(R_{\mathrm{f}}=0.6\right.$ in $9: 1 \mathrm{v} / \mathrm{v}$ hexane/ethyl acetate) then afforded E-7-(chloromethylene)-4,5,6,7,-tetrahydro-2methylbenzofuran (23/27) (114 mg, 82\%) as a clear, colorless oil. ${ }^{1} \mathrm{H}$ NMR (400 MHz, $\left.\mathrm{CDCl}_{3}\right) \delta 6.25(\mathrm{~s}, 1 \mathrm{H}), 5.86(\mathrm{~s}, 1 \mathrm{H}), 2.59-2.52$ (complex m, 2H), $2.47(\mathrm{t}, J=6.1 \mathrm{~Hz}, 2 \mathrm{H}), 2.27$ (s, 3H), 1.86-1.78 (complex m, 2H); ${ }^{1} \mathrm{H}$ NMR (300 MHz C $\left.6 \mathrm{D}_{6}\right) \delta 6.40(\mathrm{~s}, 1 \mathrm{H}), 5.58(\mathrm{~s}, 1 \mathrm{H})$, $2.41(\mathrm{tm}, J=7.0 \mathrm{~Hz}, 2 \mathrm{H}), 2.13(\mathrm{t}, J=6.0 \mathrm{~Hz}, 2 \mathrm{H}), 1.94(\mathrm{~s}, 3 \mathrm{H}), 1.54$ (dq, $J=7.0$ and $6.0 \mathrm{~Hz}$, $2 \mathrm{H}) ;{ }^{13} \mathrm{C}$ NMR $\left(100 \mathrm{MHz}, \mathrm{CDCl}_{3}\right) \delta 151.9,146.4,128.9,122.7,107.3,106.9,25.8,23.1$, 22.5, 13.7; ${ }^{13} \mathrm{C}$ NMR (75 MHz, $\left.\mathrm{C}_{6} \mathrm{D}_{6}\right) \delta 151.9$ (C2), 146.8 (C9), 129.4 (C8), 122.9 (C4), 107.5 (C3), 107.3 (10), 26.0 (C6), 23.2 (C5), 22.5 (C7), 13.4 (C11); IR v $v_{\max }$ 3080, 2939, 2847, 1550, 1254, 1138, 898, $799 \mathrm{~cm}^{-1}$; MS m/z (EI, $\left.70 \mathrm{eV}\right) 184$ and $182\left(\mathrm{M}^{+\bullet}, 36\right.$ and 100\%), 147 (24), 119 (25), 91 (25), 43 (40); HRMS found: $\mathrm{M}^{+\bullet}, 182.0498 . \mathrm{C}_{10} \mathrm{H}_{11}{ }^{35} \mathrm{ClO}$ requires $\mathrm{M}^{+\bullet}, 182.0498$. The ca. $15 \% \mathrm{C} 7{ }^{13} \mathrm{C}$-labeled formed of compound $\mathbf{2 3} / \mathbf{2 7}$ was obtained using the same procedure as defined above but using ca. $15 \%{ }^{13} \mathrm{C}$-labeled precursor 19 in place of unlabelled material. Comparison of the ${ }^{13} \mathrm{C}$ NMR spectra of the unlabeled and labeled materials indicated a ca. 15 fold enhancement of the signal at $\delta_{\mathrm{C}}\left(75 \mathrm{MHz}, \mathrm{C}_{6} \mathrm{D}_{6}\right) 107.5(\mathrm{C} 3)$ in the latter case.

\section{1-Ethoxycyclohexene (29)}

1-Ethoxycyclohexene (29) was prepared in the manner described by Wohl ${ }^{12}$. Thus, a magnetically stirred solution of cyclohexanone (28) $(10 \mathrm{~mL}, 9.5 \mathrm{~g}, 97 \mathrm{mmol})$ and triethyl orthoformate $(17.7 \mathrm{~g}, 120 \mathrm{mmol})$ maintained at $0{ }^{\circ} \mathrm{C}$ (ice/water bath) was treated with $p$ toluenesulfonic acid $(190 \mathrm{mg}, 1.0 \mathrm{mmol})$ in three roughly equal portions over $3 \mathrm{~min}$. The ensuing mixture was warmed to $22{ }^{\circ} \mathrm{C}$, maintained at this temperature for $18 \mathrm{~h}$ then heated to $150{ }^{\circ} \mathrm{C}$ for $18 \mathrm{~h}$ in an apparatus that allowed the ethanol, ethyl formate and triethyl orthoformate to be distilled from the reaction mixture. Distillation of the ensuing light-orange oil and collection of the fraction boiling in the range $150-160{ }^{\circ} \mathrm{C}$ at $760 \mathrm{~mm} \mathrm{Hg}$ gave variable mixtures, as judged by ${ }^{1} \mathrm{H}$ NMR analysis, of 1-ethoxycyclohexene (29) ${ }^{12}$ and cyclohexanone diethyl ketal (quantitative yield). This material was used, without purification, in the next step of the reaction sequence 


\section{1-Methoxycyclohexene (30)}

1-Methoxycyclohexene (30) was prepared in the same manner as described above for the formation of 1-ethoxycyclohexene (29) save for the use of trimethyl orthoformate in place of triethyl orthoformate and using a heating temperature and time of $110{ }^{\circ} \mathrm{C}$ and $2 \mathrm{~h}$, respectively. Distillation of the ensuing light-orange oil and collection of the fraction boiling in the range $138-140{ }^{\circ} \mathrm{C}$ at $760 \mathrm{~mm} \mathrm{Hg}$ gave a ca. 3:2 mixture, as judged by ${ }^{1} \mathrm{H}$ NMR analysis, of 1-methoxycyclohexene (30) $)^{12}$ and cyclohexanone dimethyl ketal (quantitative yield). This material was used, without purification, in the next step of the reaction sequence.

\section{7,7-Dichloro-1-ethoxybicyclo[4.1.0]heptane (31)}

The title compound 31 was prepared from 1-ethoxycyclohexene (29) (8.47 g, $67.0 \mathrm{mmol})$ using the general method for the formation of gem-dihalocyclopropanes as described above. The dark-brown oil obtained after work-up was subjected to flash chromatography (silica, 99:1 $\rightarrow$ 98:2 v/v hexane/ethyl acetate gradient elution). Concentration of the appropriate fractions $\left(R_{\mathrm{f}}=0.4\right.$ in 9:1 v/v hexane/ethyl acetate $)$ then afforded 7,7-dichloro-1ethoxybicyclo[4.1.0]heptane (31) ${ }^{6}(7.48 \mathrm{~g}, 54 \%)$ as light-yellow oil. ${ }^{1} \mathrm{H}$ NMR (400 MHz, $\mathrm{CDCl}_{3}$ ) $\delta 3.69$ (m, 2H), 2.20-1.97 (complex m, 3H), $1.76(\mathrm{dd}, J=9.5$ and $2.4 \mathrm{~Hz}, 1 \mathrm{H}), 1.65-$ 1.52 (complex m, 1H), 1.50-1.34 (complex m, 3H), $1.24(\mathrm{~m}, 4 \mathrm{H}) ;{ }^{13} \mathrm{C}$ NMR $(100 \mathrm{MHz}$, $\left.\mathrm{CDCl}_{3}\right) \delta$ 69.3, 64.1, 62.4, 33.6, 23.8, 21.1, 20.2, 19.2, 15.2; IR $v_{\max } 2977,2941,2878,1444$, $1380,1202,1117,1073,1045,916,904,815 \mathrm{~cm}^{-1}$; MS m/z (EI, $\left.70 \mathrm{eV}\right) 175$ and 173 [(M$\mathrm{Cl} \bullet)^{+}, 30$ and 89\%), 147 and 145 (34 and 100), 111 and 109 (28 and 61), 81 (10); HRMS found: $(\mathrm{M}-\mathrm{Cl} \bullet)^{+}, 173.0736 . \mathrm{C}_{9} \mathrm{H}_{14}{ }^{35} \mathrm{Cl}_{2} \mathrm{O}$ requires $(\mathrm{M}-\mathrm{Cl} \bullet)^{+}, 173.0733$.

\section{7,7-Dichloro-1-methoxybicyclo[4.1.0]heptane (32)}

The title compound 32 was prepared from 1-methoxycyclohexene (30) (6.00 g, $53.5 \mathrm{mmol})$ using the general method for the formation of gem-dihalocyclopropanes as described above. The dark-brown oil obtained after work-up was subjected to flash chromatography (silica, 99:1 $\rightarrow$ 98:2 v/v hexane/ethyl acetate gradient elution) and concentration of the appropriate fractions $\left(R_{\mathrm{f}}=0.4\right.$ in 9:1 v/v hexane/ethyl acetate $)$ then afforded 7,7-dichloro-1methoxybicyclo[4.1.0] heptane (32) ${ }^{14}(7.62 \mathrm{~g}, 73 \%)$ as a clear, pale-yellow oil. ${ }^{1} \mathrm{H}$ NMR (400 $\mathrm{MHz}, \mathrm{CDCl}_{3}$ ) $\delta 3.45$ (s, 3H), 2.18-1.98 (complex m, 3H), 1.74 (dd, $J=9.4$ and $\left.2.4 \mathrm{~Hz}, 1 \mathrm{H}\right)$, 1.66-1.55 (complex m, 1H), 1.50-1.35 (complex m, 3H), $1.26(\mathrm{~m}, 1 \mathrm{H}) ;{ }^{13} \mathrm{C}$ NMR $(100 \mathrm{MHz}$, $\left.\mathrm{CDCl}_{3}\right) \delta 69.2,64.8,54.3,33.3,23.0,21.1,20.2,19.2$; IR $v_{\text {max }} 2940,2859,1446,1381,1334$, $1258,1208,1110,1073,917,816 \mathrm{~cm}^{-1}$; MS m/z (EI, $\left.70 \mathrm{eV}\right) 161$ and 159 [(M-Cl•) $)^{+}, 33$ and 
100\%), 123 (23), 91 (31); HRMS found: $(\mathrm{M}-\mathrm{Cl} \bullet)^{+}, 159.0573 . \mathrm{C}_{8} \mathrm{H}_{12}{ }^{35} \mathrm{Cl}_{2} \mathrm{O}$ requires $(\mathrm{M}-\mathrm{Cl} \bullet)^{+}$, 159.0577 .

\section{(6E)-6-Chloromethylene-1-ethoxycyclohexene (33)}

The title compound $\mathbf{3 3}$ was prepared from 7,7-dichloro-1-ethoxybicyclo[4.1.0]heptane (31) $(2.00 \mathrm{~g}, 9.6 \mathrm{mmol})$ using the general method for treating of gem-dihalocyclopropanes with $t$ $\mathrm{BuOK}$ as described above. The light-yellow oil obtained after work-up was subjected to flash chromatography (silica, 98.5:1:0.5 v/v/v hexane/ethyl acetate/triethylamine elution). Concentration of the appropriate fractions $\left(R_{\mathrm{f}}=0.8\right.$ in $9: 1 \mathrm{v} / \mathrm{v}$ hexane/ethyl acetate $)$ then afforded the title diene $33(1.50 \mathrm{~g}, 91 \%)$ as a clear, colorless oil. ${ }^{1} \mathrm{H}$ NMR (400 $\mathrm{MHz}, \mathrm{CDCl}_{3}$ )

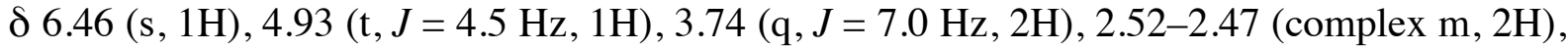
2.21-2.15 (complex m, 2H), 1.69-1.61 (complex m, 2H), $1.30(\mathrm{t}, J=7.0 \mathrm{~Hz}, 3 \mathrm{H}) ;{ }^{13} \mathrm{C} \mathrm{NMR}$ $\left(100 \mathrm{MHz}, \mathrm{CDCl}_{3}\right) \delta 150.5,133.3,113.5,100.3,62.3,26.1,24.2,22.1,14.6 ; \mathrm{IR} v_{\max } 2978$, 2932, 2878, 1637, 1375, 1236, 1180, 1123, 1046, 872, $805 \mathrm{~cm}^{-1}$; MS m/z (EI, $\left.70 \mathrm{eV}\right) 174$ and $172\left(\mathrm{M}^{+\bullet}, 27\right.$ and 80\%), 144 (26), 137 (34), 109 (100), 79 (50). The unstable nature of this material precluded the acquisition of HRMS data.

\section{(6E)-6-Chloromethylene-1-methoxycyclohexene (34)}

The title compound 34 was prepared from 7,7-dichloro-1-methoxybicyclo[4.1.0]heptane (32) $(1.00 \mathrm{~g}, 5.12 \mathrm{mmol})$ using the general method for treating gem-dihalocyclopropanes with $t$ BuOK as described above. The dark-brown oil obtained after work-up was subjected to flash chromatography (silica, 98.5:1:0.5 v/v/v hexane/ethyl acetate/triethylamine elution) and concentration of the appropriate fractions $\left(R_{\mathrm{f}}=0.6\right.$ in $9: 1 \mathrm{v} / \mathrm{v}$ hexane/ethyl acetate $)$ then afforded the title diene $34(733 \mathrm{mg}, 90 \%)$ as a clear, colorless oil. ${ }^{1} \mathrm{H}$ NMR (400 $\mathrm{MHz}$, $\left.\mathrm{CDCl}_{3}\right) \delta 6.42(\mathrm{~s}, 1 \mathrm{H}), 4.94(\mathrm{t}, J=4.5 \mathrm{~Hz}, 1 \mathrm{H}), 3.56(\mathrm{~s}, 3 \mathrm{H}), 2.55-2.45$ (complex m, 2H), 2.23-2.16 (complex m, 2H), 1.71-1.59 (complex m, 2H); ${ }^{13} \mathrm{C}$ NMR (100 $\mathrm{MHz}, \mathrm{CDCl}_{3}$ ) $\delta$ 151.3, 133.2, 113.5, 99.5, 54.2, 26.1, 24.1, 22.1; IR $v_{\max }$ 2938, 2836, 1640, 1378, 1238, 1204 , $1171,1027,890,809 \mathrm{~cm}^{-1}$; MS m/z (EI, $\left.70 \mathrm{eV}\right) 160$ and $158\left(\mathrm{M}^{+\bullet}, 24\right.$ and 63\%), $123(100), 93$ (31), 91 (93), 81 (40), 79 (93); HRMS found: $\mathrm{M}^{+\bullet}, 159.0500 . \mathrm{C}_{8} \mathrm{H}_{11}{ }^{35} \mathrm{ClO}$ requires $\mathrm{M}^{+\bullet}$, 159.0498 .

\section{E-7,7-Dichloro-2-(chloromethylene)-1-methoxybicyclo[4.1 .0]heptane (35)}

The title compound 35 was prepared from (6E)-6-chloromethylene-1-methoxycyclohexene (34) $(700 \mathrm{mg}, 4.41 \mathrm{mmol})$ using the general method for the formation of gemdihalocyclopropanes as described above. The dark-brown oil obtained after work-up was 
subjected to flash chromatography (silica, 99:1 $\rightarrow$ 98:2 v/v hexane/ethyl acetate gradient elution) and concentration of the appropriate fractions $\left(R_{\mathrm{f}}=0.4\right.$ in $9: 1 \mathrm{v} / \mathrm{v}$ hexane/ethyl acetate) then afforded E-7,7-dichloro-2-(chloromethylene)-1-methoxybicyclo[4.1.0]heptane (35) (692 mg, 65\%) as a white, crystalline solid, m.p. $=69{ }^{\circ} \mathrm{C}$ (recrystallized from $\mathrm{CH}_{2} \mathrm{Cl}_{2}$ /hexane). ${ }^{1} \mathrm{H} \mathrm{NMR}\left(400 \mathrm{MHz}, \mathrm{CDCl}_{3}\right) \delta 6.56$ (s, 1H), 3.30 (s, 3H), 2.62 (dm, $J=16.9$ $\mathrm{Hz}, 1 \mathrm{H}), 2.22$ (m, 1H), 2.00-1.86 (complex m, 2H), 1.73-1.54 (complex m, 2H), 1.25 (m, $1 \mathrm{H}) ;{ }^{13} \mathrm{C}$ NMR $\left(100 \mathrm{MHz}, \mathrm{CDCl}_{3}\right) \delta 131.6,120.6,69.2,66.8,55.2,34.8,25.8,20.9,20.1$; IR $v_{\max } 2887,1616,1448,1111,1051834 \mathrm{~cm}^{-1}$; MS m/z (EI, $\left.70 \mathrm{eV}\right) 242$ and $240\left(\mathrm{M}^{+\bullet}, 2\right.$ and 3\%), 209, 207 and 205 [(M-Cl• $)^{+}, 13,64$ and 100\%], 179 and 177 (14 and 21); HRMS found: $(\mathrm{M}-\mathrm{Cl} \bullet)^{+}, 205.0184 . \mathrm{C}_{9} \mathrm{H}_{11} \mathrm{Cl}_{3} \mathrm{O}$ requires $(\mathrm{M}-\mathrm{Cl} \bullet)^{+}, 205.0187$.

\section{E-7-(Chloromethylene)-5,6,7,8-tetrahydrobenzofuran (36)}

The title compound $\mathbf{3 6}$ was prepared from E-7,7-dichloro-2-(chloromethylene)-1methoxybicyclo[4.1.0]heptane (35) $(600 \mathrm{mg}, 2.48 \mathrm{mmol})$ using the general method for the treatment of gem-dihalocyclopropanes with $t$-BuOK as described above. The dark-brown oil obtained after work-up was subjected to flash chromatography (silica, 99:1 $\rightarrow$ 98:2 v/v hexane/ethyl acetate gradient elution) and concentration of the appropriate fractions $\left(R_{\mathrm{f}}=0.6\right.$ in 9:1 v/v hexane/ethyl acetate) then afforded $E$-7-(chloromethylene)-4,5,6,7tetrahydrobenzofuran (36) (146 mg, 35\%) as a clear, colorless oil. ${ }^{1} \mathrm{H}$ NMR (400 MHz, $\left.\mathrm{CDCl}_{3}\right) \delta 7.26(\mathrm{~d}, J=1.8 \mathrm{~Hz}, 1 \mathrm{H}), 6.35(\mathrm{~s}, 1 \mathrm{H}), 6.26(\mathrm{~d}, J=1.8 \mathrm{~Hz}, 1 \mathrm{H}), 2.62-2.57$ (complex $\mathrm{m}, 2 \mathrm{H}), 2.54(\mathrm{t}, J=6.1 \mathrm{~Hz}, 2 \mathrm{H}), 1.89-1.81$ (complex m, 2H); ${ }^{13} \mathrm{C} \mathrm{NMR}\left(100 \mathrm{MHz}, \mathrm{CDCl}_{3}\right) \delta$ 148.0, 141.7, 129.0, 121.5, 111.0, 108.5, 25.8, 23.1, 22.5; IR $v_{\max } 2931,2847,1490,1146$, 1104, 894, 789, $691 \mathrm{~cm}^{-1}$; MS m/z (EI, $\left.70 \mathrm{eV}\right) 170$ and $168\left(\mathrm{M}^{+\bullet}, 33\right.$ and 100\%), $133(30), 105$ (59), 77 (30); HRMS found: $\mathrm{M}^{+\bullet}, 168.0346 . \mathrm{C}_{9} \mathrm{H}_{9} \mathrm{ClO}$ requires $\mathrm{M}^{+\bullet}, 168.0342$.

Formation of the Diels-Alder Adduct 38 [Dimethyl (E)-5-(Chloromethylene)-5,6,7,8tetrahydro-2H-2,4a-epoxynaphthalene-3,4-dicarboxylate]

A magnetically stirred solution of furan $36(60 \mathrm{mg}, 0.36 \mathrm{mmol})$ in toluene $(1.0 \mathrm{~mL})$ maintained under nitrogen was treated with DMAD (37) $(73 \mu \mathrm{L}, 84 \mathrm{mg}, 0.59 \mathrm{mmol})$ and the ensuing solution heated in a sealed tube at $50{ }^{\circ} \mathrm{C}$ for $16 \mathrm{~h}$. The resulting grey solution was cooled and then concentrated under reduced pressure to afford a brown oil. Subjection of this material to flash chromatography (silica, 95:5 v/v hexane/ethyl acetate elution) gave two fractions, A and B.

Concentration of fraction $\mathrm{A}\left(R_{\mathrm{f}}=0.6\right.$ in $9: 1 \mathrm{v} / \mathrm{v}$ hexane/ethyl acetate) gave compound 36 (25 mg, 42\% recovery) as clear, colorless oil. 
Concentration of fraction B $\left(R_{\mathrm{f}}=0.1\right.$ in $9: 1 \mathrm{v} / \mathrm{v}$ hexane/ethyl acetate $)$ gave compound 38 (13 mg, 20\% based on recovered starting material) as clear, light-yellow oil. ${ }^{1} \mathrm{H}$ NMR (400 MHz, $\left.\mathrm{CDCl}_{3}\right) \delta 6.60(\mathrm{~m}, 1 \mathrm{H}), 6.30(\mathrm{~d}, J=2.0 \mathrm{~Hz}, 1 \mathrm{H}), 5.60(\mathrm{~d}, J=2.0 \mathrm{~Hz}, 1 \mathrm{H}), 3.82(\mathrm{~s}, 3 \mathrm{H}), 3.78(\mathrm{~s}$, $3 \mathrm{H}), 3.11(\mathrm{dm}, J=15.8 \mathrm{~Hz}, 1 \mathrm{H}), 2.74(\mathrm{dm}, J=15.8 \mathrm{~Hz}, 1 \mathrm{H}), 2.35(\mathrm{~m}, 1 \mathrm{H}), 2.24(\mathrm{~m}, 1 \mathrm{H}), 2.00$ (m, 1H), 1.58-1.42 (complex m, 1H); ${ }^{13} \mathrm{C} \mathrm{NMR}\left(100 \mathrm{MHz}, \mathrm{CDCl}_{3}\right) \delta 164.8,162.7,156.8,155.9$, $150.4,134.8,132.1,117.9,93.5,82.4,52.4,52.3,26.6,26.1,23.0$; IR $v_{\max } 2952,1716,1647$, 1435, 1267, 1228, 1112, 1042, $932 \mathrm{~cm}^{-1}$; MS m/z (EI, $\left.70 \mathrm{eV}\right) 312$ and $310\left(\mathrm{M}^{+\bullet}, 5\right.$ and 14\%), 275 (43), 215 (18), 170 (44), 168 (100), 105 (19); HRMS found: $\mathrm{M}^{+\bullet}, 310.0603 . \mathrm{C}_{15} \mathrm{H}_{15}{ }^{35} \mathrm{ClO}_{5}$ requires $\mathrm{M}^{+\bullet}, 310.0608$.

\section{Dimethyl (E)-8-(Chloromethylene)-3-hydroxy-5,6,7,8-tetrahydronaphthalene-1,2-dicarboxy -late (39)}

A magnetically stirred solution of furan $36(90 \mathrm{mg}, 0.53 \mathrm{mmol})$ in toluene $(4.0 \mathrm{~mL})$ maintained under nitrogen was treated with DMAD (37) $(66 \mu \mathrm{L}, 76 \mathrm{mg}, 0.53 \mathrm{mmol})$ and the ensuing solution heated under reflux for $28 \mathrm{~h}$. The resulting grey solution was cooled and then concentrated under reduced pressure to give brown oil. Subjection of this material to flash chromatography (silica, 95:5 v/v hexane/ethyl acetate elution) gave, after concentration of the appropriate fractions $\left(R_{\mathrm{f}}=\right.$ 0.1 in 9:1 v/v hexane/ethyl acetate), compound 39 (32 mg, 28\%) as clear, yellow oil. ${ }^{1} \mathrm{H}$ NMR $\left(400 \mathrm{MHz}, \mathrm{CDCl}_{3}\right) \delta 10.98(\mathrm{~s}, 1 \mathrm{H}), 6.85(\mathrm{~s}, 1 \mathrm{H}), 6.31(\mathrm{~m}, 1 \mathrm{H}), 3.91(\mathrm{~s}, 3 \mathrm{H}), 3.86(\mathrm{~s}, 3 \mathrm{H}), 2.64$ $(\mathrm{td}, J=7.2$ and $2.1 \mathrm{~Hz}, 2 \mathrm{H}), 2.58(\mathrm{~m}, 2 \mathrm{H}), 1.77(\mathrm{~m}, 2 \mathrm{H}) ;{ }^{13} \mathrm{C} \mathrm{NMR}\left(100 \mathrm{MHz}, \mathrm{CDCl}_{3}\right) \delta 169.3$, $169.2,161.0,149.3,135.4,132.7,125.3,117.5,116.5,107.9,53.0,52.5,30.8,26.5,21.1$; IR $v_{\max }$ 2951, 1733, 1674, 1445, 1349, 1228, 1207, 1097, $1016 \mathrm{~cm}^{-1}$; MS m/z (ESI) 335 and $333\left(\mathrm{M}+\mathrm{Na}^{+}\right.$, 31 and 100\%), 313 (4), 301 (3); HRMS found: $\mathrm{M}+\mathrm{H}^{+}, 311.0687 . \mathrm{C}_{15} \mathrm{H}_{15}{ }^{35} \mathrm{ClO}_{5}$ requires $\mathrm{M}+\mathrm{H}^{+}$, 311.0686 .

\section{E-2-(Chloromethylene)- 7,7-dibromo-1-ethoxybicyclo[4.1.0]heptane (40)}

The title compound 40 was prepared from (6E)-6-chloromethylene-1-ethoxycyclohexene (33) (374 mg, $2.16 \mathrm{mmol}$ ) using the general method for the formation of gem-dihalocyclopropanes as described above. The dark-brown oil obtained after work-up was subjected to flash chromatography (silica, 99:1 $\rightarrow$ 98:2 v/v hexane/ethyl acetate gradient elution) and concentration of the appropriate fractions $\left(R_{\mathrm{f}}=0.4\right.$ in $9: 1 \mathrm{v} / \mathrm{v}$ hexane/ethyl acetate $)$ then afforded $E-2-$ (chloromethylene)-7,7-dibromo-1-ethoxybicyclo-[4.1.0]heptane (40) (377 mg, 51\%) as a lightyellow, crystalline solid, m.p. $=59-63{ }^{\circ} \mathrm{C}$ (recrystallized from $\mathrm{CH}_{2} \mathrm{Cl}_{2} /$ hexane) ${ }^{1} \mathrm{H}$ NMR (400 $\left.\mathrm{MHz}, \mathrm{CDCl}_{3}\right) \delta 6.60(\mathrm{~s}, 1 \mathrm{H}), 3.59(\mathrm{~m}, 1 \mathrm{H}), 3.37(\mathrm{~m}, 1 \mathrm{H}), 2.59(\mathrm{dm}, J=16.8 \mathrm{~Hz}, 1 \mathrm{H}), 2.35-2.23$ (complex m, 1H), 2.05-1.93 (complex m, 2H), 1.75-1.65 (complex m, 1H), 1.55-1.42 (complex 
$\mathrm{m}, 1 \mathrm{H}), 1.34-1.16$ (complex m, 4H); ${ }^{13} \mathrm{C} \mathrm{NMR} \mathrm{(100} \mathrm{MHz,} \mathrm{CDCl}_{3}$ ) $\delta$ 133.2, 120.7, 65.1, 63.6, 43.8, 36.4, 26.0, 22.5, 20.7, 15.1; IR $v_{\max }$ 2939, 1612, 1444, 1216, 1108, 1050, 815, $767 \mathrm{~cm}^{-1}$; MS m/z (EI, $70 \mathrm{eV}) 311$ and 309 [(M-Cl•) $)^{+}, 33$ and 64\%], 307 (34), 265 (41), 273 (89), 199 (38), 103 (45), 91 (100); HRMS found: $(\mathrm{M}-\mathrm{Cl} \bullet)^{+}, 306.9338 . \mathrm{C}_{10} \mathrm{H}_{13} \mathrm{Cl}^{79} \mathrm{Br}_{2} \mathrm{O}$ requires (M-Cl•) 306.9333 .

\section{Treatment of Compound 40 with Potassium tert-Butoxide. GC-MS Detection of Compounds 23/27 and 41}

Compound $\mathbf{4 0}$ was treated with potassium tert-butoxide in THF in the same manner as congener 19. The reaction mixture thus obtained was worked up in the prescribed manner and the ensuing light-yellow oil subjected to GC-MS analysis on an Agilent 5073 GC-MS Instrument fitted with a HP-5ms capillary column [20 m x $0.18 \mathrm{~mm}$ (ID)] using helium as the carrier gas and a column temperature of $50{ }^{\circ} \mathrm{C}$. The major peak (ca. 95\%) was observed after $13.42 \mathrm{~min}$. and a minor one (ca. 2-3\%) after $14.32 \mathrm{~min}$. The derived EI mass spectra are shown in Figure 6a and 6b, respectively.

\section{7,7-Dibromo-1-ethoxybicyclo[4.1.0]heptane (45)}

The title compound 45 was prepared from 1-ethoxycyclohexene (29) (3.00 g, $23.8 \mathrm{mmol}$ ) using the general method for the formation of gem-dihalocyclopropanes described above. The darkbrown oil obtained after work-up was subjected to flash chromatography (silica, 99:1 $\rightarrow$ 98:2 v/v hexane/ethyl acetate gradient elution). Concentration of the appropriate fractions $\left(R_{\mathrm{f}}=0.4\right.$ in 9:1 $\mathrm{v} / \mathrm{v}$ hexane/ethyl acetate) then afforded 7,7-dibromo-1-ethoxybicyclo[4.1.0]heptane (45) ${ }^{14}(6.03$ $\mathrm{g}, 61 \%)$ as clear, light-brown oil. ${ }^{1} \mathrm{H}$ NMR $\left(400 \mathrm{MHz}, \mathrm{CDCl}_{3}\right) \delta 3.72(\mathrm{~m}, 2 \mathrm{H}), 2.22-2.03$ (complex m, 3H), $1.90(\mathrm{dd}, J=9.7$ and $2.3 \mathrm{~Hz}, 1 \mathrm{H}), 1.52-1.39$ (complex m, 4H), 1.30-1.21 (complex m, 4H); ${ }^{13} \mathrm{C}$ NMR (100 MHz, $\left.\mathrm{CDCl}_{3}\right) \delta$ 63.5, 61.8, 45.0, 35.3, 24.8, 21.3, 21.2, 20.2, 15.2; IR $v_{\max } 2938,1443,1374,1187,1115,1070,1042,896,764 \mathrm{~cm}^{-1}$.

\section{3-Ethoxycyclohept-2-en-1-one (47) and 3-(tert-Butoxy)cyclohept-2-en-1-one (48)}

The title compounds were formed upon treating 7,7-dibromo-1-ethoxybicyclo[4.1.0]heptane (45) (1.00 g, $3.36 \mathrm{mmol})$ with $t$-BuOK using the general method described above. The brown oil obtained after work-up was subjected to flash chromatography (silica, 9:1 $\rightarrow$ 1:1 v/v hexane/ethyl acetate gradient elution). Concentration of the appropriate fractions $\left(R_{\mathrm{f}}=0.1\right.$ in $9: 1$ $\mathrm{v} / \mathrm{v}$ hexane/ethyl acetate) then afforded a ca. 2:5 mixture of compounds $\mathbf{4 7} 7^{24}$ and 48 (943 $\mathrm{mg}$, $71 \%$ ) as a clear, light-brown oil. Resubjection of a small fraction of this material to further flash chromatographic purification under the same conditions and concentration of a few early or late 
fractions allowed for the isolation of spectroscopically pure samples of each of compounds $\mathbf{4 7}$ and 48.

Compound $47{ }^{1} \mathrm{H}$ NMR (400 MHz, $\mathrm{CDCl}_{3}$ ) $\delta 5.34$ (s, 1H), 3.76 (q, $J=7.0 \mathrm{~Hz}, 2 \mathrm{H}$ ), 2.60-2.48 (complex m, 4H), 1.86-1.71 (complex m, 4H), $1.31(\mathrm{t}, J=7.0 \mathrm{~Hz}, 3 \mathrm{H}) ;{ }^{13} \mathrm{C}$ NMR $(100 \mathrm{MHz}$, $\left.\mathrm{CDCl}_{3}\right) \delta 202.3,176.2,105.7,64.1,41.6,32.9,23.4,21.2,14.1 ;$ IR $v_{\max } 2941,1644,1604,1377$, $1180 \mathrm{~cm}^{-1}$; MS m/z (ESI) $177\left(\mathrm{M}+\mathrm{Na}^{+}, 100 \%\right), 155$ (5); HRMS found: $\mathrm{M}+\mathrm{H}^{+}$, 155.1066. $\mathrm{C}_{9} \mathrm{H}_{14} \mathrm{O}_{2}$ requires $\mathrm{M}+\mathrm{H}^{+}, 155.1072$.

Compound 48: ${ }^{1} \mathrm{H}$ NMR (400 MHz, $\left.\mathrm{CDCl}_{3}\right) \delta 5.52(\mathrm{~s}, 1 \mathrm{H}), 2.53(\mathrm{~m}, 2 \mathrm{H}), 2.45(\mathrm{~m}, 2 \mathrm{H}), 1.82-$ 1.70 (complex m, 4H), 1.41 (s, 9H); ${ }^{13} \mathrm{C}$ NMR (100 MHz, $\mathrm{CDCl}_{3}$ ) $\delta$ 202.7, 174.2, 109.3, 80.0, $41.3,34.2,28.2,23.4,21.0 ;$ IR $v_{\max } 2938,1638,1595,1368,1245,1156,1138,884 \mathrm{~cm}^{-1}$; MS m/z (ESI, +ve) $205\left(\mathrm{M}+\mathrm{Na}^{+}, 100 \%\right), 149$ (7), 127 (6); HRMS found: $\mathrm{M}+\mathrm{H}^{+}, 183.1381 . \mathrm{C}_{11} \mathrm{H}_{18} \mathrm{O}_{2}$ requires $\mathrm{M}+\mathrm{H}^{+}, 183.1385$.

\section{Crystallographic Studies on Compounds 19,35 and 40}

\section{Crystal data}

Compound 19: $\mathrm{C}_{10} \mathrm{H}_{13} \mathrm{Cl}_{3} \mathrm{O}, M=255.55, T=150 \mathrm{~K}$, triclinic, space group $\mathrm{P}-1, Z=2, a=$ 7.3031(6), $b=8.9170(7), c=9.1413(8) \AA ̊ 8=81.507(7)^{\circ}, \beta=85.452(7)^{\circ}, \gamma=80.354(7)^{\circ}$; $V=579.54(8) \AA^{3}, D_{x}=1.464 \mathrm{~g} . \mathrm{cm}^{-3}, 2712$ unique data $\left(2 \theta_{\max }=60.2^{\circ}\right), 2141$ with $I>2 \sigma(I) ; R$ $=0.041, R w=0.091, S=1.06$.

Compound 35: $\mathrm{C}_{9} \mathrm{H}_{11} \mathrm{Cl}_{3} \mathrm{O}, M=241.54, T=200 \mathrm{~K}$, orthorhombic, space group Pna $2_{1}, Z=4$, $a=8.4239(4), b=16.5510(7), c=7.5180(3) \AA ; V=1048.19(8) \AA^{3}, D_{x}=1.531 \mathrm{~g} . \mathrm{cm}^{-3}, 2366$ unique data $\left(2 \theta_{\max }=55^{\circ}\right), 2096$ with $I>3 \sigma(I) ; R=0.0218, R w=0.0263, S=1.1034$.

Compound 40: $\mathrm{C}_{10} \mathrm{H}_{13} \mathrm{Br}_{2} \mathrm{ClO}, M=344.47, T=150 \mathrm{~K}$, triclinic, space group $\mathrm{P}-1, Z=2, a=$ 7.4888(5), $b=8.8924(6), c=9.2043(6) \AA \AA \alpha=83.085(6)^{\circ}, \beta=86.309(6)^{\circ}, \gamma=81.870(6)^{\circ}$; $V=601.67(7) \AA^{3}, D_{x}=1.901 \mathrm{~g} . \mathrm{cm}^{-3}, 2828$ unique data $\left(2 \theta_{\max }=60.2^{\circ}\right), 2141$ with $I>2 \sigma(I) ; R$ $=0.040, R w=0.098, S=1.06$.

\section{Structure Determination}

Images were measured on a Nonius Kappa CCD diffractometer (MoKa, graphite monochromator, $\lambda=0.71073 \AA$ ) and the data extracted using the CrysAlis package. The structures of compounds 19, 35 and 40 were solved with ShelXT ${ }^{25}$ and refined using ShelXL ${ }^{26}$ in OLEX2. ${ }^{27}$ Atomic coordinates, bond lengths and angles, and displacement parameters have been deposited at the Cambridge Crystallographic Data Centre (CCDC no. 
1852815-1852817). These data can be obtained free-of-charge via www.ccdc.cam.ac.uk/data_request/cif, by emailing data_request@ccdc.cam.ac.uk, or by contacting The Cambridge Crystallographic Data Centre, 12 Union Road, Cambridge CB2 1EZ, UK; fax: +44 1223336033.

\section{ASSOCIATED CONTENT}

\section{Supporting Information}

Cif and anisotropic displacement ellipsoid plots from the single-crystal X-ray analyses of compounds 19, 35 and 40. ${ }^{1} \mathrm{H}$ and/or ${ }^{13} \mathrm{C}$ NMR spectra of compounds 19, 23/27, 29-36, 38, 39, 40, 45, 47 and 48. This material is available free-of-charge via the Internet at http://pubs.acs.org.

\section{AUTHOR INFORMATION}

\section{Corresponding Author}

*Tel: +61-2-6125-8202. Fax: +61-2-6125-8114. E-mail: Martin.Banwell@anu.edu.au

\section{ORCID}

Martin G. Banwell: 0000-0002-0582-475X

\section{Author Contributions}

The manuscript was written through contributions from all of the authors. All of the authors have given approval to the final version of the manuscript.

\section{Notes}

The authors declare no competing financial interest.

\section{ACKNOWLEDGMENTS}

The authors thank the Australian Research Council, the Institute of Advanced Studies at the Australian National University for financial support.

\section{REFERENCES}

1. For a discussion of the methods available for the generation of dihalocarbenes see: (a) Banwell, M. G.; Reum, M. E. gem-Dihalocyclopropanes in Chemical Synthesis, in Advances in Strain in Organic Chemistry (ed. B. Halton), JAI Press, London, 1991, 1, 19-64; (b) Fedorynski, M. Syntheses of gem-Dihalocyclopropanes and Their Use in Organic Synthesis, Chem. Rev., 2003, 103, 1099-1132; (c) Halton, B.; Harvey, J. Electrocyclic Ring-Opening Reactions of gem-Dibromocyclopropanes in the Synthesis of natural products and Related Compounds, Synlett. 2006, 1975-2000. 
2. (a) Banwell, M. G.; Beck, D. A. S.; Stanislawski, P. C.; Sydnes, M. O.; Taylor, R. M. Pyrroles and gem-Dihalocyclopropanes as Building Blocks for Alkaloid Synthesis

Curr. Org. Chem., 2005, 9, 1589-1600 and references cited therein; (b) Stanislawski, P. C.; Willis, A. C. ; Banwell, M. G. gem-Dihalocyclopropanes as Building Blocks in Natural-Product Synthesis: Enantioselective Total Syntheses of ent-Erythramine and 3-epi-Erythramine Chem. Asian J., 2007, 2, 1127-1136.

3. Banwell, M. G.; Gable, R. W.; Halton, B.; Phyland, J. R. Dehydrohalogenation of the Bis-dihalocarbene Adducts of Some Methoxycyclohexa-1,4-dienes: Revision of Product Structures. Aust. J. Chem., 1994, 47, 1879-1884.

4. Banwell, M. G.; Phillis, A. T.; Willis, A. C. Exploitation of Cyclopropane Ring-cleavage Reactions for the Rapid Assembly of Tetracyclic Frameworks Related to Gibberellins.Org. Lett., 2006, 8, 5341-5344.

5. For a useful point of entry into the literature on this topic see Blanchet, J.; Macklin, T.; Ang, P.; Metallinos, C.; Snieckus, V. Directed Ortho Metalation/Cross-Coupling Strategies. N-Cumyl Arylsulfonates. Facile Deprotection and Expedient Route to 7and 4,7-Disubstituted Saccharins. J. Org. Chem., 2007, 72, 3199-3206.

6. Banwell, M. G.; Corbett, M.; Gulbis, J.; Mackay, M. F.; Reum, M. E. Generation and Solution-phase Behaviour of Some 2-Halogeno-1,3-ring-fused Cyclopropenes $J$. Chem. Soc., Perkin Trans. 1, 1993, 945-963.

7. For a review on thermally-induced cyclopropene to carbene rearrangements see Baird, M. S. Thermally Induced Cyclopropene-Carbene Rearrangements: An Overview. Chem. Rev., 2003, 103, 1271-1294.

8. Foot, J. S.; Phillis, A. T.; Sharp, P. P.; Willis, A. C.; Banwell, M. G. Dichlorocarbene Adducts of Alkyl Enol Ethers as Precursors to Furans: Application to a Total Synthesis of the Furanosesquiterpene ( \pm )-Pallescensin A Tetrahedron Lett., 2006, 47, 6817-6820.

9. Müller, P.; Pautex, N. From Dichlorocyclopropanes to Furans and Cyclopentadienes via Vinylcarbenes. Helv. Chem. Acta, 1988, 71, 1630-1637.

10. These types of ring-closures are well documented. For a review see Huisgen, R. 1,5Electrocyclizations - An Important Principle of heterocyclic Chemistry. Angew. Chem. Int. Ed. Engl., 1980, 19, 947-973. For more recent examples see Reisser, M.; Maas, G. Synthesis of Pyrroles from 1-Dialkylamino-3-phophoryl(or phosphanyl)allenes Through 1,5-Cyclization of Conjugated Azomethine Ylide Intermediates. J. Org. Chem., 2004, 69, 4913-4924. 
11. We chose to conduct our investigations using ethoxy-substituted cyclopropanes because the derived C2-methylated furans tend to be more stable than the equivalent non-methylated systems produced by the reactions of the corresponding methoxysubstituted cyclopropanes.

12. Wohl, R. A. Convenient One-step Procedure for the Synthesis of Cyclic Enol Ethers. Preparation of 1-Methoxy-1-cycloalkenes. Synthesis, 1974, 38-40.

13. Makosza, M.; Wawrzyniewicz, M. Reactions of Organic Anions. XXIV. Catalytic Method for Preparation of Dichlorocyclopropane Derivatives in Aqueous Medium Tetrahedron Lett., 1969, 4659-4662.

14. Parham, W. E.; Soeder, R. W.; Throckmorton, J. R.; Kuncl, K.; Dodson, R. M. Reactions of Enol Ethers with Carbenes. V. Rearrangements of Dihalocyclopropanes Derived from Six-, Seven-, and Eight-Membered Cyclic Enol Ethers, J. Am. Chem. Soc., 1965, 87, 321-328.

15. Bissember, A. C.; Phillis, A. T.; Banwell, M. G.; Willis, A. C. Base-Promoted Reactions of Dichlorocarbene Adducts of Cyclic Enamines: A New Route to Annulated Pyrroles Org. Lett., 2007, 9, 5421-5424.

16. Pangborn, A. B.; Giardello, M. A.; Grubbs, R. H.; Rosen, R. K.; Timmers, F. J. Safe and Convenient Procedure for Solvent Purification. Organometallics 1996, 15, 1518 1520.

17. Still, W. C.; Kahn, M.; Mitra, A. Rapid Chromatographic Technique for Preparative Separations with Moderate Resolution. J. Org. Chem. 1978, 43, 2923-2925.

18. Frisch, M. J.; Trucks, G. W.; Schlegel, H. B.; Scuseria, G. E.; Robb, M. A.; Cheeseman, J. R.; Scalmani, G.; Barone, V.; Mennucci, B.; Petersson, G. A.; Nakatsuji, H.; Caricato, M.; Li, X.; Hratchian, H. P.; Izmaylov, A. F.; Bloino, J.; Zheng, G.; Sonnenberg, J. L.; Hada, M.; Ehara, M.; Toyota, K.; Fukuda, R.; Hasegawa, J.; Ishida, M.; Nakajima, T.; Honda, Y.; Kitao, O.; Nakai, H.; Vreven, T.; Montgomery, Jr., J. A.; Peralta, J. E.; Ogliaro, F.; Bearpark, M.; Heyd, J. J.; Brothers, E.; Kudin, K. N.; Staroverov, V. N.; Kobayashi, R.; Normand, J.; Raghavachari, K.; Rendell, A.; Burant, J. C.; Iyengar, S. S.; Tomasi, J.; Cossi, M.; Rega, N.; Millam, N. J.; Klene, M.; Knox, J. E.; Cross, J. B.; Bakken, V.; Adamo, C.; Jaramillo, J.; Gomperts, R.; Stratmann, R. E.; Yazyev, O.; Austin, A. J.; Cammi, R.; Pomelli, C.; Ochterski, J. W.; Martin, R. L.; Morokuma, K.; Zakrzewski, V. G.; Voth, G. A.; Salvador, P.; Dannenberg, J. J.; Dapprich, S.; Daniels, A. D.; Farkas, Ö.; Foresman, J. B.; Ortiz, J. V.; Cioslowski, J.; Fox, D. J. Gaussian 09, Gaussian, Inc., Wallingford CT, 2009. 
19. Werner, H-J.; Knowles, P. J.; Knizia, G.; Manby, F. R.; Schütz, M. and ohers, MOLPRO, a Package of Ab Initio Programs, version 2009.1.

20. Henry, D. J.; Sullivan, M. B.; Radom, L. G3-RAD and G3X-RAD: Modified Gaussian-3 (G3) and Gaussian-3X (G3X) Procedures fro Radical Thermochemistry. $J$. Chem. Phys. 2003, 118, 4849-4869.

21. Scott, A. P.; Radom, L. Harmonic Vibrational Frequencies: An Evaluation of HartreeFock, Møller-Plesset, Quadratic Configuration Intercation, Density Functional Theory, and Semiempirical Scal Factors. J. Phys. Chem. 1996, 100, 16502-16513.

22. Marenich, A. V.; Cramer, C. J.; Truhlar, D. G. J. Universal Solvation Model Based on Solute Electron Density and on a Continuum Model of the Solvent Defined by the Bulk Dielectric Constant and Atomic Surface Tensions. Phys. Chem. B 2009, 113, 6378-6396.

23. Eckart, C. The Penetration of a Potential Barrier by Electrons. Phys. Rev. 1930, 35, 1303-1309.

24. Thompson, G. S.; Hirsh, J. A. Ambident Reactivity of Medium-Ring Cycloalkane-1,3dione Enolates. J. Org. Chem. 1998, 63, 1098-1101.

25. Sheldrick, G. M. SHELXT - Integrated Space-Group and Crystal-Structure Determination. Acta Cryst, 2015, A71, 3-8.

26. Sheldrick, G. M. Crystal Structure Refinement with SHELXL. Acta Cryst, 2015, C71, 3-8.

27. Dolomanov, O. V.; Bourhis, L. J.; Gildea, R. J.; Howard, J. A. K.; Puschmann, H. OLEX2: A complete structure solution, refinement and analysis program, J. Appl. Cryst., 2009, 42, 339-341. 